原著

\title{
無細胞セメント質に見られる成長線の構造に関する観察
}

\author{
李衍 江 \\ 東京医科歯科大学歯学部第一口腔解剖学教室（指導：山下靖雄教授）
}

(1996 年 6 月 28 日 受付)

\section{Observations of the Structure of Incremental Lines in Acellular Cementum}

\author{
Yan-Jiang Li
}

First Department of Oral Anatomy, School of Dentistry, Tokyo Medical and Dental University

(Director : Prof. Yasuo Yamashita)

The purpose of this study was to investigate the function of human cementum from a morphological viewpoint. To accomplish this purpose, the incremental lines in human acellular cementum were studied by light microscopy, microradiogram (CMR), scanning electron microscopy, and transmission electron microscopy, and the results were as follows :

1. In acellular cementum, many fine incremental lines of about $0.5 \mu \mathrm{m}$ width were observed.

2. The fine incremental lines were observed running perpendicularly or obliquely to Sharpey's fibers in the acellular cementum.

3. The fine incremental lines observed in acellular cementum were not straight lines but had wave-like structure. fibers.

4. Each wave observed in the fine incremental lines corresponded to a bundle of Sharpey's

5. The fine incremental lines observed on Sharpey's fibers in acellular cementum showed specific characteristic features.

6. Despite the fine incremental lines showing a close relationship to the degree of calcification, they also seemed to show a strong relationship to the quality of the organic component of the acellular cementum.

7. Apart from the fine incremental lines which are specific to acellular cementum, incremental lines similar to those observed in cellular cementum were also observed within the acellular cementum. These incremental lines were wider and their degree of calcification was higher.

\section{I . 緒言}

歯根の表面を覆っているセメント質は, エナメ ル質や象牙質とともに歯を構成する硬組織の一つ である。また，セメント質は歯を歯槽骨（顎骨） に固定するためのシャーピー線維を埋め込んでお
り，歯根膜，歯槽骨ならびに歯肉とともに歯牙支 持装置 (歯周組織) としての役割の一端を担って いる ${ }^{125}$ 。このセメント質は, 萌出後も咬合状態の 微妙な変化や種々の刺激に反応し, 形成, ときに は吸収を繰り返すことが知られている ${ }^{3 \sim 11)}$ 。と もと, セメント質はその所在部位によってかなり 
形態や構造に差が見られるうえに，このように咬 合圧の変化や周囲組織からもたらされるさまざま な刺激によって，二次的な構造変化が生ずること が多いため，歯牙支持装置として重要な機能を 持った組織であるにもかかわらず，いまだにその 本態に関しては不明な点が多いのが現状である。 しかし，近年，高齢化社会を迎え，歯牙の機能的 な延命を四ることがますます重要となってきてい ることから，セメント質を含む歯周組織の機能を 形態学的に究明し, 歯周疾患の予防と治療を推進 するための基礎的知見を得ることが急務であると 思われる。

従来からセメント質は, 無細胞セメント 質1,6,7,10,12,13) (原生セメント質7,10,12,14,15) ) と，(有)細 胞セメント質 $1,6,7,12,13$ ) (第二セメント質 $1,4,7,10,12,15)$ ) などに便宜的に区別されている。著者は「解剖学 用語」 ${ }^{16)} に$ 従って，ここでは無細胞セメント質 (Cementum noncellulare) と, 細胞セメント質 (Cementum cellulare）という用語を使用するこ とにする。セメント質はシャーピー線維を多く含 むことから，Weidenreich ${ }^{17)}$ の骨の分類によると， 線維骨の仲間に入ると考えられている。セメント 質のシャーピー線維は，主として歯根膜の線維芽 細胞によって産生される extrinsic fiber（外部性 線維, 非固有性線維) ${ }^{3,6,13,18,19)}$ であり，セメント芽 細胞によって産生されて, intrinsic fiber（固有性 線維） $3,6,13,18,19)$ に相当する基質線維と異なるとい われており，細胞の有無のほかに，この両者の線 維の量的な関係がセメント質の構造と性格を規定 していると考えられている。細胞セメント質は シャーピー線維が少なく，その反面，基質線維が よく発達し，骨層板と同様な層板構造 ${ }^{2}$ を形成し ている部位も見られるとともに, 細胞（セメント 細胞）が埋入されている状態が見られることなど から，骨組織（線維骨組織）に類似しているとい える ${ }^{4)}$ 。この細胞セメント質（第二セメント質）の 基質線維の構造に関しては，すでに本教室の陳 ${ }^{2)}$ らの詳細な報告が見られる。前述したように，無 細胞セメント質は, シャーピー線維が特に多く存

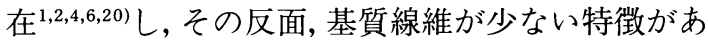

ク，形成速度も遅いと考えられており，硬組織の なかでもかなり特殊化した組織であるといえ る2)。しかし，無細胞セメント質は，細胞セメント 質に比べて全般的に薄く ${ }^{1,2,4)}$ ，また，比較解剖学的 見地から見ると，無細胞セメント質は運動性の少 ない歯に見られるという意見尔もあるが，ヒトで は，歯頸部付近に位置していることから，歯根が 露出するとただちに口腔内環境にさらされ，さま ざまな刺激の侵襲を受ける部位でもあるととも に，歯頸部は咬合圧が歯に加わった場合に，その 部は根のなかでも比較的動摇範囲の大きい4)部分 でもあると考えられ，歯を固定する機能は甚大で あるといえる。また，この無細胞セメント質の領 域にも，多数の成長線梯の構造物が認められ，硬 組織に見られるこのような成長線は，その部の形 成速度や構造の周期的な変化の状態を知ることが できる。また，歯においては，この成長線がう蝕 の進行とも関連性のあることが多くの研 究11,12,21 30)で認められている。そのようなことか ら，無細胞セメント質の成長線の構造と性格を知 ることによって，セメント質の機能を形態学的に 究明する糸口を得るとともに，う蝕の予防などに 関する基礎的資料を得ることができるものと考 え，本論文では無細胞セメント質に見られる成長 線の構造的特徵を光学ならびに電子顕微鏡を用い て検討を行った。

\section{II. 材料と方法}

\section{1. 材料}

ヒトの健全な切歯 (30 本)，小臼歯（10 本）な らじに大臼歯（10 本）を材料として用いた。

\section{2. 方法}

1) 光学顕微鏡による観察

(1) 研磨標本

抜去歯を $10 \%$ 中性ホルマリンで固定した。これ らの標本について厚さ約 $50 \mu \mathrm{m}$ の縦断研磨標本 を作製した。これらの研磨標本について無染色(無 染色研磨標本）のままで観察し，一部の標本につ いては 0.1 規定の塩酸にて，15 30 秒間酸腐蝕を 行って，ヘマトキシリン染色前(酸腐蝕研磨標本) 
と染色後（ヘマトキシリン染色研磨標本）に観察 を行った。また，一部の研磨標本については，そ れが完全に脱灰されるまで酸で脱灰を行い，その 同一標本についてへマトキシリン・エオジン染色 前（無染色脱灰研磨標本）と染色後（へマトキシ リン・エオジン染色脱灰研磨標本）に観察を行っ て比較した。さらに, 一部の研磨標本については, microradiogram (CMR) で観察した。用いた装 置は Sofron SRO-M 50 で，撮影条件は管電圧 12 $\mathrm{KV}$ ，管電流 $4 \mathrm{~mA}$ で露出時間は 50 分間である。 撮影された CMR 像を光学顕微鏡で観察した。

\section{(2) 脱灰切片}

抜去歯を $10 \%$ 中性ホルマリンで固定後，5\%の ギ酸にて脱灰を行った後, 通法に従ってパラフィ ン包埋を行い, 縦断ならびに横断切片を作製した。 これらの切片にへマトキシリン・エオジン染色, アザン染色，ならびに PAP 鍍銀染色 (変法)を施 して観察を行った。また，一部のアザン染色切片 については脱色後, 再び同一切片にへマトキシリ ン・エオジン染色を施して染色性を比較した。

2 ）走査電子顕微鏡による観察

抜去歯を $10 \%$ 中性ホルマリンで固定後, 縦断研 磨面を作製し，一部の標本については, 0.1 規定塩 酸にて $60 \sim 90$ 秒間酸腐蝕を行い, また一部の標本 については，5\%の次亜塩素酸ナトリウムを研磨 面に作用させ脱有機処理を施した。これらの標本 について通法に従って脱水, 臨界点乾燥を行い, さらにカーボンと金の二重蒸着を施して走査電子 顕微鏡で観察した。

3 ）透過電子顕微鏡による観察

抜歯後，ただちに $2 \%$ glutaraldehyde（pH 7.4 sodium cacodylate buffer， $4{ }^{\circ} \mathrm{C}$ ) で 2 時間前固定 を行った。さらに $2 \%$ OsO 4 (pH 7.4, sodium cacodylate buffer， $\left.4^{\circ} \mathrm{C}\right)$ にて 4 時間後固定を行っ た。その後, 通法に従って脱水し, エポキシ樹脂 に包埋を行い，未脱灰超薄切片を作製した。それ らの超薄切片を未染色のまま，あるいは切片上で 酢酸ウラニルとクエン酸鉛の二重電子染色を行っ て透過電子顕微鏡で観察した。

\section{III. 所見}

\section{1. 光学顕微鏡所見}

1 ) 研磨標本

無染色研磨標本で観察を行うと, 無細胞セメン 卜質（原生セメント質）には, 明調な線条の構造 物（ライン）と暗調な線条の構造物（ライン）が 交互に配列し，それらが基本的にはセメント質表 面，ならびにセメント・象牙境に対してほぼ平行 に配列しているのが認められる(図 10)。これらの 構造物は一種のセメント質の成長線であると思わ れることから, 以後, これらの構造物を成長線と 呼ぶことにする。暗調なラインも明調なラインも ほぼ均一な幅と間隔を呈しているが，場所によっ て多少幅や間隔に差が見られる場合もある。また， それらのラインがともに明瞭に出現している部位 もあれば，やや不明瞭な部位も見られる。

無染色研磨標本に酸をわずかに作用させた標本 (酸腐蝕研磨標本) で観察を行うと，セメント質の 表面に対して直角方向ないしはやや斜め方向に配 列しているシャーピー線維の束の輪郭を認めるこ とができる(図 11)。明・暗のラインを拡大して観 察すると, それらは必ずしも直線的ではなく, 細 かい波状の形態をしている。個々の波状の湾曲は シャーピー線維の束と一致して，それぞれの束の 境界部で屈曲している状態が見られる(図 11)。ま た，シャーピー線維の束が均一で，しかも配列方 向が一定している部位では，これらの微細な成長 線も明瞭となっているのに対して，シャーピー線 維の束やその輪郭が不明瞭で配列が乱れている部 位では, 成長線も全般的に不明瞭となっている（図 11)。さらに, 酸腐蝕研磨標本にへマトキシリン染 色（図 1）を施して観察を行うと，無染色の場合 と同様に線条の構造物からなる成長線が認められ るが，これらの成長線は特異的にへマトキシリン に染色されるような状態はほとんど認められな い。しかし， $2 \sim 3$ 本程度の明瞭な線状構造物が 観察される場合には，それらのラインはへマトキ シリンに染色されている。

完全に脱灰されるまで研磨標本に酸を作用させ 
てから観察を行うと，無処置あるいはわずかに酸 を作用させた研磨標本の場合と異なって，明・暗 の線条構造からなる微細な成長線は，やや不明瞭 となっている(図 12-A)。しかし，コントラスト を上げて観察を行うと，成長線ならびにシャ一 ピー線維の走行が確認できる。さらに，この脱灰 研磨標本を観察後，その同一標本にへマトキシリ ン染色を施して観察を行うと, 成長線はへマトキ シリンに染色されるラインと染色されないライン とが交互に配列した状態で認められる（図 12-B)。さらに，無染色のままで撮影した写真と 染色後撮影した写真について同一部位を写真上で 重ね合わせて，それぞれの成長線を対応させてみ ると, 無染色標本で暗調に見えるラインは, 染色 標本では，へマトキシリンに染色されるラインと ほぼ一致することが確かめられた(図 12)。同様に 無染色標本で明調に見えるラインは, 染色標本で は，へマトキシリンにほとんど染色されないライ ンとほぼ一致することも確認された。

研磨標本の CMR 像（図 14）で観察を行うと, 通常のセメント質の領域と比較して，X線の透過 度がやや低いラインと, 透過度が高いラインが見 られ，それらが不明瞭ながらセメント質の表面に ほぼ平行に配列している状態が認められる。いず れにしても，これらのラインの数は全般的に少な く，幅も広い。このうち，X線透過度の低いライ ンは, 2 3 本程度観察され, 透過度の高いライン に比べて一般に明暸な場合が多い。

2 ) 脱灰切片

(1) 無染色切片

脱灰パラフィン切片をキシロールにて脱パラ フィンを行った後, カバーグラスのみで仮封入し て観察すると，通常の研磨標本の場合と同様に 明・暗の線条構造物からなる多数の微細な成長線 が観察される(図 13-A)。脱灰パラフィン切片の 場合には，完全に脱灰を行った研磨標本の場合よ りも成長線が明瞭に観察されるとともに，より細 かい成長線まで認めることができる。また, シャ一 ピ一線維の輪郭も比較的明暸に認められる。
（2）へマトキシリン・エオジン染色切片

脱灰切片にへマトキシリン・エオジン染色を施 して観察を行うと，無細胞セメント質は全般的に へマトキシリンに対する染色性がエオジンに対す る染色性よりも高い傾向が見られる（図 2，3， 15)。無細胞セメント質にはへマトキシリンに濃く 染色される暗調なラインと，へマトキシリンに染 色されず，エオジンに淡染する明調なラインから なる微細な成長線様の構造物が明瞭に観察され る。この成長線の幅は, 平均 $0.5 \mu \mathrm{m}$ 程度となって いる。しかし，へマトキシリンに濃く染色される ラインはきわめて幅の狭いものから，かなり幅の 広いものまでさまざまである。これらのへマトキ シリンに染色されるラインの間に位置する明調な ラインの幅にも差が見られる。また，場所によっ て両者のラインの幅がほぼ同程度で，それらのラ インが数本の単位でまとまって走行している場合 も見られる(図 $2 ， 3 ， 15$ )。一般に幅の狭いライ ンほど均一な幅であるが，ラインの幅が全般的に 広いものは，それらの幅もかなりばらつきが見ら れる。また，へマトキシリンに染色されるライン のうちでも，特に濃く染色される暗調で幅の広い ラインが 1 ～ 3 本程度観察される場合もある（図 $2 ， 5)$ 。なお，標本によってはこのラインに沿っ て亀裂が生じている場合もある(図 5 )。脱灰切片 にへマトキシリン・エオジン染色を施した切片で は，それぞれのシャーピー線維の辺縁部付近がへ マトキシリンに染色される傾向が見られる(図 2 , 3 )。これらの切片においても，研磨標本の場合と 同様に明調なラインも，暗調なラインもシャ一 ピ一線維の単位で波状の湾曲を呈しており，その 凸面はセメント質の表面側を向いていることが多 い。セメント質の最表層の領域を拡大して観察す ると，へマトキシリンに染色されている石灰化前 線と思われる部分が，同様に個々のシャーピー線 維の単位で波状の湾曲を呈している状態が認めら れる(図 4)。その際, 最表層が一層へマトキシリ ンに濃染するライン（暗調なライン）となってい る場合と，最表層がそれよりへマトキシリンに対 する染色性が低く，エオジンに淡染する明調なラ 
インを構成している場合とが見られる。そのうち， 特に明調なラインに注目してみると，個々の シャーピー線維に見られるこの明調なラインの輪 郭は, 石灰化前線の形態と一致する状態が見られ る(図 4 )。また，これらのライン状の構造物の配 列状態は，前述した無細胞セメント質の領域の全 般にわたって見られる，いわゆる明調なラインと 暗調なラインとからなる, 微細な成長線様の構造 物とほぼ一致している。

脱灰パラフィン切片を無染色のままで観察を 行った切片と同一切片にへマトキシリン・エオジ ン染色を施して，無染色と染色後に出現する成長 線をそれぞれ比較してみると，無染色切片で暗調 となっているラインは，へマトキシリン・エオジ ン染色では，へマトキシリンに染色されるライン と一致し，また，無染色切片で明調となっている ラインは, へマトキシリン・エオジン染色を行っ た場合には，へマトキシリンにほとんど染色され ない明調なラインとほぼ一致することが確認され た（図 13-A，B）。

(3) アザン染色

脱灰切片にアザン染色を施して観察を行うと， アニリン青あるいはアゾカルミンに染色されるラ イン（暗調ライン）と，それらの色素にあまり染 色されない明調なラインからなる多数の微細な成 長線様の構造物が観察される(図 6，7)。これら の両ラインともに同一ラインにおいては，その全 長にわたって，幅がほぼ一定しているが，場所に よってそれらのラインの幅ならびに間隔が多少異 なっている場合もある。アザン染色切片を観察後 脱色を行い，その同一切片に，へマトキシリン・ エオジン染色を施して，アザン染色とへマトキシ リン・エオジン染色による染色性を比較してみる と，へマトキシリンに染色されるラインは，アゾ カルミンあるいはアニリン青に染色される暗調な ラインと一致することが確かめられた(図 9 )。ま た，へマトキシリン・エオジン染色切片における 明調なラインは，アザン染色切片における明調な ラインと一致し，このラインはへマトキシリン・ エオジン染色ならびに，アザン染色においていず
れも色素にあまり染色されないことが確認され た。しかし，セメント・象牙境や成長線の間隔が 広く, シャーピー線維の基質のみが存在している と思われるような部分，ならびに，特にへマトキ シリンに濃染し, やや幅の広い暗調なライン（1 〜 3 本程度) は, 通常の成長線とは逆に, アザン 染色切片では明調な部分, ないしは明調なライン となっているのが認められる(図 9)。また，アザ ン染色切片（図 6 ）で1〜3本程度見られる染色 性の低い明暸なラインは，そのラインに沿って亀 裂が生じていることが多い。また，脱灰アザン染 色切片では, シャーピー線維の束がアニリン青に 染色される部分とアゾカルミンに染色される部分 とが認められる(図 7，8)。しかし，場所によっ てはシャーピー線維がアニリン青に全般的に淡染 している部分も見られる。これらの染色性は シャーピー線維ごとに違う場合もあれば，同一の シャーピー線維においても, 部分的に染色性の違 いが見られることもある。アニリン青に淡染する シャーピー線維が多く見られる領域では, 全般的 にシャーピー線維自体も細く，また，その配列も 乱れている場合が多い(図 7)。そのような部位に おいては, 微細な成長線様の構造物も不明瞭と なっている傾向が見られる。

アザン染色を施した切片で, 特に無細胞セメン ト質の表層部を観察すると, 全般的にこの部は深 層部の領域に比べて，アゾカルミンにやや濃く染 色される傾向が見られる(図 8)。シャーピー線維 と歯根膜線維との移行部, すなわち石灰化前線に 相当する部分では, シャーピー線維がアゾカルミ ンに染色されているのに対して，未石灰化のコ ラーゲン線維からなる歯根膜の主線維は, アニリ ン青によって青く染色されている(図 8 )。アゾカ ルミンに染色されている石灰化前線の部分は, シャーピー線維の単位ごとに歯根膜側に向かって 凸湾した形態を呈していることが多い。このよう に全般的にアゾカルミンに染まっている表層部の 領域をさらに拡大して観察を行うと, 最先端のみ が一層アゾカルミンに濃く染色される層が見ら れ，それが隣接のものと連続してライン状をなし 
ている状態も見られる。しかし，場所によっては， そのアゾカルミンに濃染しているラインの層が最 表面からわずかに離れて，その表面にはむしろそ れより染色性が低くなっている層も見られ，それ がその部位のシャーピー線維の染色性と同程度 か，あるいはそれよりやや低い染色性を示してい る場合もある。また，このような層も連続してラ イン状の形態を呈している状態も見られる（図 $8)$ 。アゾカルミンに対する染色性が, 表層部から 順次深層側に向かって全般的に低下寸るのに伴っ て，アゾカルミンに濃く染まるラインも，淡染す るラインも順次染色性が低くなり, 特に後者のラ インは，色素にあまり染まらない明調なラインに 移行するような傾向も見られる。

(4) PAP 鍍銀染色

脱灰切片に PAP 鍍銀染色を施して観察を行う と，銀によって黒染された線状の構造物（ライン） と，銀にほとんど染色されない明調な線条の構造 物が多数観察される(図 16 18)。また，この染色 切片では, シャーピー線維が銀にやや濃く染色さ れている。しかし，個々のシャーピー線維のうち でも辺縁部は銀に染色されることなく，比較的明 調な状態となっていることが多い。前述した好銀 性の線条構造物は, シャーピー線維よりさらに銀 に濃く染色される明瞭なラインも見られるが, シャーピー線維の染色性とほぼ同程度の染色性を 示しているものも見られる。前者のラインは一般 に幅も一定しているが，後者のラインは幅があま ク一定することなく, きわめて細いものから, 極 端に幅が広いものまで見られる。また，銀にほと んど染まらない明調なラインも見られるが，その 明調なラインは，時としてきわめて幅が広く，し かも，明瞭なものが $2 \sim 3$ 本程度見られる場合が ある（図 18）。このようなラインの前後では, シャーピー線維の配列方向が変化している場合も 見られる。なお，通常の暗調なラインも明調なラ インも研磨標本や他の染色法を施した脱灰切片の 場合と同様に，細かい波状の湾曲が見られ，それ らが個々のシャーピー線維の単位で生じており, その湾曲の凸部はセメント質の表層側を向いてい
ることが多い(図 16，17)。また，歯根膜線維はセ メント質のシャーピー線維の染色性同様, やや濃 く染まっている（図 16，17）。

\section{2. 電子顕微鏡所見}

1 ）走查電子顕微鏡所見

(1) 酸腐蝕研磨面

研磨面に酸を作用させた後，その表面を走査電 子顕微鏡で観察すると，ところどころにわずかに 酸によって腐蝕されて陥凹した溝状の構造物が観 察される(図 19)。これらはセメント質の表面にほ ぼ平行に走行し, シャーピー線維に対してはほぼ 直交する方向に配列しており，一種の成長線であ ると思われる。また，これらの成長線は必ずしも 連続したライン状の構造物として出現するとは限 らず，その陥凹の程度も隣接するシャーピー線維 でそれぞれ異なっていることが多い。走査電子顕 微鏡で認められるこれらの溝状の構造物は, 光学 顕微鏡で観察されるものより，全般的に数が少な く,また, その間隔も広く, きわめて不明瞭な状 態となっている。ときには, 個々のシャーピー線 維の単位で, 比較的細かい溝状の陥凹が数本の単 位でまとまって見られることもあるが，そのよう な状態はごくまれである。

\section{(2) 脱有機研磨面}

研磨面を次亜塩酸ナトリウムで処理した後，そ の表面を走査電子顕微鏡で観察を行うと，セメン 卜質の表面に対してほぼ平行な方向に走行する多 数の溝状の構造物が観察される(図 20２2）。酸腐 蝕研磨面ならびに脱灰研磨面の場合と比べて, 脱 有機を行った標本の場合には，より細かい溝状の 構造物が多数出現する傾向が見られる。これらの 溝状の構造物は，比較的規則的に配列している部 分で計測すると, 平均 $0.5 \mu \mathrm{m}$ 程度となっており, 光学顕微鏡において観察された微細な成長線とほ ぼ同じ間隔で配列している部位も見られる。また， これらの線状構造物も光学顕微鏡において観察さ れたように，不明瞭ながら個々のシャーピー線維 の単位で屈曲ないしはわずかな湾曲が見られ，そ れらが連続して一本の成長線を構成している状態 も認められる（図21，22）。 
2 ）透過電子顕微鏡所見

（1）未脱灰未染色超薄切片

未脱灰超薄切片を作製し, 未染色のままで透過 電子顕微鏡を用いて観察すると, シャーピ一線維 に対して直交ないしやや斜め方向で，セメント質 の表面に対してはほぼ平行な方向に走行している 電子密度のやや高い部分と低い部分が見られ，そ れらが交互に配列して成長線様の形態をなしてい る状態がところどころに認められる(図 23)。これ らの構造物は光学顕微鏡において認められた微細 な成長線様の構造物と同様に, 個々のシャーピー 線維の単位でごくわずかに湾曲している状態も認 められる。しかし, シャーピ一線維の配列が乱れ ているような部位では，これらの構造物を観察す ることがほとんどできない。いずれにしてもこの 両者のラインは電子密度の差が比較的少なく，ま たこのようなラインを認めることができる部位は ごく限られている。

（2）未脱灰電子染色超薄切片

未脱灰超薄切片に電子染色を施して, 透過電子 顕微鏡で観察を行うと, 電子密度の高い部分と低 い部分が交互に配列して，それぞれ細かい成長線 様の形態をなしているのが明瞭に認められる（図 24２8）。これらの成長線様の形態をなしているラ インは, 基本的には光学顕微鏡標本の場合と同様 に，セメント質の表面に対してほぼ平行な方向に 配列している。また，これらのラインも細かい波 状の形態をしており，それらが個々のシャーピー 線維の単位で屈曲あるいは湾曲している状態も見 られる(図 24〜28)。その波状湾曲の凸部は，ほと んどの場合セメント質の表面側を向いている。電 子密度の高いラインと低いラインがそれぞれ均一 の幅で，等間隔に並んで規則的な成長線様の配列 状態を示している部位も見られる(図 25)。そのよ うな部位で電子密度の高いラインならびに低いラ インの幅を計測してみると, 平均 $0.45 \mu \mathrm{m}$ 程度と なっている。場所によっては, 両者ともその幅, 間隔ともに一定せず,かなりばらつきも見られる。 同一ラインでも隣接のシャーピー線維に移行する と，とたんにその幅，間隔とも狭くなり，また，

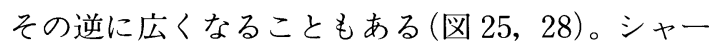
ピー線維が斜断されているような断面に見られる ラインは, シャーピー線維が縦断されている断面 に出現しているラインに比べて全般的に幅, 間隔 ともに広くなるとともに，波状の湾曲の程度もや や弱くなる傾向が見られる（図 25，28）。シャー ピ一線維の部分は全般に電子密度が高い場合が多 いが，なかには電子密度がやや低いこともある。 また，個々のシャーピー線維の辺縁部付近は，一 般に電子密度が低くなっている傾向が見られる (図 25，26)。電子密度の高い暗調なラインも, 電 子密度の低い明調なラインも, 電子密度が高い シャーピー線維の部分を通過する際には, 同一ラ インでもその部分だけ電子密度がやや高くなる状 態が見られる(図 27，28)。しかし, 電子密度が高 いラインも低いラインも，基本的には微細な粒子 状ないしは結晶様の形態をした構造物が観察され る。電子密度が高い部分は, そのような構造物が 密に存在している（図 28）。

\section{IV. 考察}

Shimamine ${ }^{15)}$ は，セメント質を原生セメント質 と第二セメント質に分け，また第二セメント質は 無細胞性のへマトキシリンに濃染する層が織り込 まれていて，この層を層板間層と名付けた。以来， この層板間層の構造に関して多くの観察 ${ }^{4,7}$ がな されている。近年では，この構造物は骨組織に見 られる休止線 ${ }^{31 \sim 36)} に$ 相当し，また一種の成長 線3,6,7,12,14,37)であると考えられている。また，この セメント質の成長線は，一般に石灰化の良好な部 位であるという見解 $4,6,7,12,38 \sim 40)$ が多い。また，なか には石灰化の良好な成長線と，それに伴行する石 灰化不全の部位が隣接していて，脱灰や脱有機な どの処理によってその部に段差が生ずるという報 告 ${ }^{40)}$ 見られる。一方, 無細胞セメント質(原生セ メント質）にも，成長線が出現することが確認さ れている ${ }^{6,12,41,42)}$ 。この成長線は石灰化度が高いと いう報告6も見られるが，いまだにその構造的特 徵や形成由来などに関しては不明な点が多い。 


\section{1. 光線ならびにX 線の透過性と成長線の関連性 について}

無細胞セメント質について, 研磨標本を作製し, 無処置のままで，通常の光学顕微鏡を用いて観察 を行うと, 明調なラインと暗調なラインとからな る多数の線条構造物が認められる。これらの線条 構造物は，セメント質表面ならびにセメント・象 牙境に対してほぼ平行な方向に配列しており，一 種のセメント質の成長線であると考えられる。ま た，これらの構造物とほぼ同様の形態をした無細 胞セメント質の成長線梯構造物に関しては, 従来 からいくつかの報告6,12,42)が見られる。無染色研磨 標本で出現するこの線条構造物は, 顕微鏡の絞り を操作し，コントラストを上げた状態で観察を行 うと，より明瞭なラインとして出現するものであ $\eta, そ の$ 部の光線の透過性の差によって明暗の差 が出るものと解される。すなわち, 光線の透過性 の良好な部分は明調なラインとなり, 一方, 光線 の透過性が不良な部分は暗調なラインとして出現 寸るものと思われる。従来から，歯や骨などの石 灰化硬組織においては，このように光線透過性の 良い部分は悪い部分に比べて, 一般に石灰化度が 高いといわれてきている4)。しかし, 光線の透過性 の良否は，その部の組織の密度にも左右されるも のであり，隣接の部分より密度が高い場合には， そこを通過する光線の散乱が少なく，したがって， 光の散乱の多い隣接部より透過光が多い分，明る く見えることになる4)。石灰化硬組織においては， 結晶などの量が増し, 石灰化が立進することに よってその部の密度が上がると考えるのが常道で あるが，エナメル質は例外としても，象牙質なら びにセメント質は相当量の有機成分7)を含んでお ク，いかに石灰化硬組織といえども，その部の密 度を決定する要素を石灰化のみに求め, 有機成分 を度外視するわけにはいかないと思われる。その ような観点に立つと, 本研磨標本において, 光線 透過性の良好な部分（明調ライン）を不良な部分 (暗調ライン)より石灰化度が高い部分と結論する ことはできない。また，この $50 \sim 70 \mu \mathrm{m}$ 程度の厚 さの研磨標本において, 顕微鏡の焦点位置を変化
させることにより, 明・暗のラインが反転する現 象も見られ，特に厚い研磨標本においてはそのよ うな傾向が強い。

研磨標本にわずかに酸を作用させて観察を行う と, 未処理のままの研磨標本に比べて, 多少成長 線がそれより明瞭となる。これは酸によってて表面 が腐蝕され，セメント質の無機成分が部分的に溶 解消失するために，光線の透過性による明暗の差 がより強調されたとも考えられるが，逆にそれに よって明暗が反転する可能性のあることも否定で きない。それを確認するためには，同一切片を用 いて未処理の所見と, 酸処理後の所見を同一ライ ンで比較すればよいのであるが, 前述したように, 厚みのある研磨標本においては焦点距離の変化に よる影響などもあって，厳密に同一ラインと同定 することはかなり困難である。

研磨標本を長時間酸に浸漬して，完全に脱灰を 行ってから，再度観察を行うと，そのような石灰 塩分を除去した後の研磨標本（脱灰研磨標本）に おいても, 無処置の研磨標本 (無染色研磨標本) および酸腐蝕研磨標本において出現する成長線と 同様の線条構造物を，それよりやや不明瞭ながら も認めることができる。したがって，この成長線 は，下地となっているコラーゲン線維などの有機 成分に，もともと光線透過性の違いが生ずるよう な密度の差が存在していたか，あるいは石灰化に よって，それらの下地が二次的に構造変化 ${ }^{2,43 \sim 46)}$ したかのどちらかであると推察される。厚さ 5 $\mu \mathrm{m}$ の通常の脱灰パラフィン切片を脱パラフィン を行って, 無染色のままの状態で観察を行っても, 同様に成長線様の構造物が認められ，しかも，50 $\mu \mathrm{m}$ 前後の厚さの脱灰研磨標本の場合より明瞭に 観察される。脱灰切片のようなかなり薄い切片に おいても，このように成長線が明瞭に認められる ことは，下地の有機成分に生じている構造変化が 一次的にせよ，二次的にせよ，かなり微妙なもの であることを物語っていると思われる。また，脱 灰切片の方が脱灰研磨標本より薄いため, 微細な ラインであってもそれらが重なり合うことが少な く，したがってこのライン状の構造物がより鮮明 
に見えるものと解される。

従来から，石灰化硬組織の石灰化度を検討する 目的で, microradiogram (CMR) による観察が 行われている。そのような方法によって，成長線 (線条構造物) の石灰化度を評価している研 究6,31,40,47,48) も多く見られる。

著者も無細胞セメント質の部分について, 研磨 標本を作製し CMR で観察を行った。その結果, 無 細胞セメント質には, 通常の領域に比べて, X線 透過性がやや低いラインと, 高いラインが不明瞭 ながら認められ，これらはいずれもセメント質表 面にほぼ平行に配列していることから，成長線の 一種であると思われる。しかし，X線の透過性も 先に述べた光線の透過性の場合と同様に，その部 に存在する物質の密度あるいはX線の吸収度に

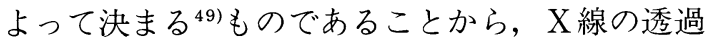
度が低いからといって，それのみで，ただちにそ の部の石灰化度が高いとはい之ない放が，石灰化 硬組織においては，X線の透過性が石灰化度の差 異を示す一応の目安とされている。

\section{2. シャーピー線維と成長線の関係について}

研磨標本の表面を酸でわずかに腐蝕して観察を 行うと, 無細胞セメント質のシャーピ一線維の束 の輪郭が比較的明瞭に認められるようになる。ま た，脱灰切片における未染色切片，へマトキシリ ン・エオジン染色切片, アザン染色切片, PAP 鍍 銀染色切片においても同様である。さらに, セメ ント質の研磨面に酸および次亜塩素酸ナトリウム を作用させて観察を行った場合にも，その表面構 造の違いによってある程度シャーピー線維の走行 と輪郭を認めることができる。もちろん, 透過電 子顕微鏡による超薄切片の観察においても, シャーピー線維を構成しているコラーゲン線維の 配列状態や結晶の沈着状態などを観察することが できる。無細胞セメント質はシャーピー線維が豊 富1,2,4,6,13,39)で，それらが下地のコラーゲン線維の 大部分を占めていることが知られている。これら のシャーピー線維はセメント・象牙境からセメン 卜質の表面に向かって走っている ${ }^{4)}$ が, 同じ無細 胞セメント質においても, その存在部位の違いや,
また同一部位でも，局所的にシャーピー線維の走 向や線維の構成状態が異なることもよく知られて いる ${ }^{6,39,50)}$ 。著者の観察においても，無細胞セメン 卜質にはシャーピー線維が密で，太い束をなして おり，それらが基本的にはセメント・象牙境ある いはセメント質表面に対して直交する方向，ある いはやや斜め方向に配列している状態が認められ る。研磨標本，脱灰切片ならびに超薄切片で見た 場合に，このように比較的太いシャーピー線維が 明瞭な束をなして整然と配列しているような部位 では, 微細な線条構造物からなる成長線が明瞭に 観察されることが多い。しかし，シャーピー線維 が細く，その配列が乱れ，明瞭な束を構成するよ うな状態が認められない部分では，成長線様の構 造物も全般的に不明瞭となる傾向がある。シャ一 ピ一線維の束が明瞭で，それらの線維の束が整然 と比較的平行に規則性を持って配列しているよう な領域に出現している微細な成長線を拡大して観 察すると，それぞれの成長線は全体としてシャー ピー線維の長軸に対して，ほぼ直交するような方 向に走行しているが，それぞれの成長線には細か い波状の湾曲が見られ，それらの個々の湾曲は， 個々のシャーピー線維の単位で生じており, 隣接 するシャーピー線維の境界部で屈曲している状態 が認められる。しかも，波状の湾曲の凸部は，七 メント質の表面側を向いていることが多い。未脱 灰超薄切片に電子染色を施して，透過電子顕微鏡 で観察した場合にも，電子密度の高いラインと低 いラインが交互に配列して出来る微細な成長線様 の構造物が観察されるが,この成長線においても， シャーピー線維の単位で湾曲と屈曲が認められ, また，その成長線の幅や間隔などの状態から見て， 電子顕微鏡で見られるこれらの成長線は, 光学顕 微鏡で観察される微細な成長線に相当するもので あると思われる。光学顕微鏡で見られる明・暗の ラインや染色性の高·低によって出現するこれら の成長線様の構造物は，いずれもその幅，間隔と もに変化に富んでいる。しかし，なかには幅，間 隔とも一定し，かなり規則的な成長線の形態をな している部位もあり，そのような部位は決まって 
その成長線の幅, 間隔ともに狭いという傾向が見 られる。また，それぞれのラインは，明調（色素 嫌性）なラインも，また，暗調（色素好性）なラ インも，光学顕微鏡で観察するかぎりでは，同一 ラインにおいては，ほぼ一定の幅となっているよ うに見えるが，超薄切片を作製し，透過電子顕微 鏡で見ると，同一ラインでも，隣のシャーピー線 維に移行すると幅, 間隔ともに多少変化している。 超薄切片上で, シャーピ一線維が縦断されている ような線維に見られる成長線が, 斜断ないし横断 に近い断面のシャーピー線維に移行する際には, その成長線の幅, 間隔ともにわずかに広くなる傾 向が見られ, 波状の湾曲の程度も多少弱くなる。 このことから，この成長線はもともと幅の広いも のも，狭いものもあるが，同一ラインではある程 度一定の幅や間隔を有しているが, 超薄切片上で は, 出現するシャーピー線維の断面によって, 幅, 間隔とも多少変化して見えることが理解される。 いずれにしても, 無細胞セメント質に見られるこ れらの微細な成長線は, シャーピー線維上に出現 するもので，その下地となっているシャーピー線 維の線維構成, 配列状態などの影響を受けて消長 し, また形態も変化するもので, 石灰化硬組織に あって，通常の基質線維がほとんどなく，それを シャーピー線維が代行しているような構造となっ ている無細胞セメント質に出現する特有の成長線 であるといえる。

無細胞セメント質においては，前述したような 微細な多数の成長線のほかに, 脱灰切片において $2 \sim 3$ 本程度, ヘマトキシリン・エオジン染色で はへマトキシリンに染色される暗調なライン，ア ザン染色と PAP 染色では色素や銀にほとんど染 まらない明調なラインが明瞭に観察されることが ある。このラインは一般に幅が広くそれを境とし て, シャーピー線維の配列方向が変化することが 多く，また，細胞セメント質（第二セメント質） がその表面に添加形成されていることもある。し かし，無細胞セメント質特有の微細な成長線は, その前後でシャーピー線維の配列方向が変化する ようなことはなく，また，シャーピー線維あって
の構造物と考えられるのに対し, $2 \sim 3$ 本程度出 現する幅の広い明瞭な成長線様の構造物は, 後述 するように，それと別種な成長線と思われる。

\section{3. 成長線の構造的特徵について}

未脱灰の未染色超薄切片について透過電子顕微 鏡で観察を行うと, 無細胞セメント質の領域には, 結晶がやや密に沈着している部分とそれよりやや 疎な部分とが交互に配列している層が見られる。 これらの層はシャーピー線維に対して直交ないし やや斜め方向に交差するように走行し，しかも全 体としてはセメント質表面にほぼ平行な方向に配 列している。この層は，その配列方向と幅などの 状態から見て, 光学顕微鏡において観察された無 細胞セメント質特有の微細な成長線にほぼ一致す るものであると思われる。結晶の沈着度の差に よって，このように成長線が出現する部位もある ことは事実であるが, このように未脱灰未染色超 薄切片で不明瞭ながら成長線様の構造物が確認で きるのはきわめてまれである。したがって，無細 胞セメント質に見られるこれらの微細な成長線 は，細胞セメント質 (第二セメント質 $)^{4,6,7,12,39,40) や ~}$

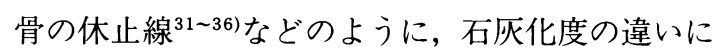
よって比較的明瞭に認められる成長線とは，かな り異なった性格のものである可能性が高い。

脱灰切片にへマトキシリン・エオジン染色を施 して観察を行うと，無細胞セメント質には，へマ トキシリンに好染する暗調なラインと, へマトキ シリンに染色されず，エオジンに淡染する明調な ラインが交互に配列して微細な成長線様の構造を 呈している状態が見られる。明調なラインも暗調 なラインも場所によって幅, 間隔ともに差が見ら れる。しかし, 幅, 間隔ともに狭いものでは, そ れらが一定となり，全般的に規則的な成長線の状 態を示す傾向が見られる。

従来から歯や骨組織の脱灰切片において, へマ トキシリン・エオジン染色を施して観察した場合, 一般にへマトキシリンに染色される部分は, エオ ジンに染色される部分に比べて石灰化度が高いと いう報告が多く見られる 4,6,31,32,51,52)。また，石灰化 硬組織においてへマトキシリンに染色される部位 
は，そこに塩基好性の物質が他の部分に比べて多 く存在している可能性もあるが, へマトキシリン は, カルシウムとレーキを形成し，石灰沈着をき たした基質を染め出すともいわれており，脱扊切 片で見られる石灰化部のへマトキシリン可染性 は，脱灰後にもなお残存して，カルシウムとへマ トキシリンとの反応によって染まるという考えも ある ${ }^{52 \sim 54)}$ 。石灰化硬組織においては, 石灰化が進 行するとその下地をなしている基質線維の一部が 損傷を受け，そのような線維は脱灰によって部分 的に溶失し, その面が陥凹するか, あるいは微細 な凹凸が生ずることが，本教室の研究によって認 められており ${ }^{43,55,56)}$, このような面にもへマトキ シリンが付着することから, 脱灰切片のへマトキ シリン好染部位が石灰化良好部位であることの説 明がなされている。著者が観察を行ったセメント 質においても, シャーピー線維の辺縁部が中軸部 に比べてへマトキシリンに青染する傾向が見ら れ，すでに多くの報告で知られているように， シャーピー線維の場合には, 石灰化不全の中軸部 に比べて，辺縁部の石灰化が良好となっていると 思われることから, 本切片においても, 石灰化の 良好な部位がへマトキシリンに染色される傾向が あるとする説明を裏付けているように思われる。 このような観点に立ってみた場合, へマトキシリ ン・エオジン染色を施した脱灰切片において，へ マトキシリンに好染している暗調なラインは, へ マトキシリンにほとんど染まらない明調なライン に比べ, 石灰化度が高くなっている部位であると もいえる。脱灰切片にアザン染色を施して観察を 行うと, アニリン青あるいはアゾカルミンに染色 されるライン (暗調ライン) と, それらの色素に あまり染まらない明調なラインからなる多数の微 細な成長線様の構造物が認められる。アザン染色 は結合組織の線維成分（主として膠原線維）と, 筋線維や他の細胞成分を色分けするためには有効 な染色法で, 古くから活用されてきている57)。ま た, このアザン染色やマッソントリクローム染色 などの染色法を歯や骨などの硬組織に応用して, その脱灰切片における所見と電子顕微鏡や CMR
像の所見と比較して, 石灰化の状態なども検討さ

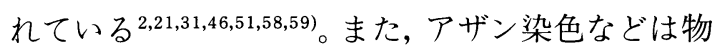

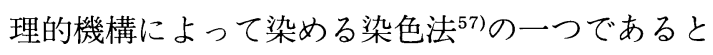
も考えられており，その理論によれば，最も粗構 な部分には最も大きいアニリン青の色素粒子が入 $\eta$, 次いでアゾカルミンの色素粒子が入り, 最も 密構な部分には, 最も粒径の小さいオレンジ Gの 色素粒子が入ると考えられている ${ }^{57)}$ 。そのような 理論に従えば, 著者が観察を行った無細胞セメン ト質でアニリン青あるいはアゾカルミンなどに染 色されるラインは，それらの色素粒子が入り込む 適当な間隙が存在していたと考えられる。一方, これらの色素に染まらない明調なラインは, これ らの色素粒子が入り込む余地がないほど密構な部 分であるか，その反対に間隔が大きすぎて色素粒 子が付着することが不可能な部分であったかのど ちらかであると推測される。本来, 同一シャーピー 線維においては, 何本かの微細な成長線が存在す る程度の範囲に限ってみれば，その部の下地をな している線維自体に形成時には，それほど構造的 な違いがあったとは考えられない。とすれば，脱 灰切片で色素粒子が入っていない明調なラインの 部分は，石灰化の元進によってその部が損傷を受 (2,43 46), 脱灰後色素粒子が付着できないほど局 部的に結晶の溶解とともに線維成分が消失してし まったか，あるいは逆に，その明調部には，脱灰 による結晶の溶出後も多量の有機成分などが残存 していて，色素粒子がそこに入り込む余地がない ほど密構な部分であったかのどちらかである可能 性が高い。しかし, 後述するように無細胞セメン 卜質のうち, 石灰化前線（セメント質最表面）近 くにおいては，アゾカルミンに淡染するものの， その深層に向かうと, この色素にほとんど染色さ れない明調なラインに移行している状態が認めら れる。形成後の時間経過や形成期か休止期かに よっても異なるが, 通常, 石灰化硬組織において は，一般に石灰化前線（セメント質表面）近くで は, 下地のコラーゲン線維が酸でかなりの量が溶 出するほどまで急激に石灰化が進行する状態には いたらないであろうという考えに立てば，この色 
素に染色されない明調なラインは, 石灰化が特に 立進している部分であるという考えにはいたらな いように思われる。

アザン染色切片について観察後, 脱色を行い, その同一切片に再びへマトキシリン・エオジン染 色を施して，アザン染色とへマトキシリン・エオ ジン染色による染色性を比較してみると, アゾカ ルミンあるいはアニリン青に染色される暗調なラ インは, ヘマトキシリンに染色される同じく暗調 なラインと一致することが確認され，アザン染色 でほとんど色素に染まらない明調なラインは，へ マトキシリンにもほとんど染まらない同じく明調 なラインと一致することが確認された。脱灰へマ トキシリン染色切片において著者が考察した見解 を，この同一切片における染色性を比較した所見 に当てはめてみると, へマトキシリンに染色され る暗調ライン，すなわち，アザン染色でアニリン 青あるいはアゾカルミンに染まる暗調ラインは, ヘマトキシリンにほとんど染色されない明調なラ イン，すなわちアザン染色でも色素にほとんど染 まらない明調なラインより, やや石灰化が立進し ている可能性もあると思われる。研磨標本に酸腐 蝕を行ってへマトキシリン染色を施した切片にお いては，ほとんどへマトキシリンに染まるライン は出現せず, また, 研磨面に酸腐蝕を行って走査 電子顕微鏡で見た場合には, 微細な成長線に相当 すると思われるラインがごくわずか認められる程 度であり，また，未脱灰未染色超薄切片で結晶の 沈着度の差によって出現する線条構造物は, ごく わずか認められるにすぎないことなどから，この 無細胞セメント質に見られる微細な成長線は, 通 常のエナメル質の成長 線4,7,13,56,60)，骨の休止 線 $\left.{ }^{31} 36\right)$, あるいは細胞セメント質（第二セメント 質)の成長線3,6,7,12,14,19,37)などに見られるような, 明 瞭な石灰化度の差によって出現する成長線様の構 造物と, やや性格を異にするのではないかと思わ れる。研磨面に次亜塩素酸ナトリウムを作用させ て, 脱有機処理を行ってその表面の形態を見てみ ると, 表面に酸処理を行った場合より, 細かい溝 状の構造が多く出現し, いわゆる光学顕微鏡で見
られる微細な成長線様の構造物に相当するものが 多く出現する。このようなことを考え合わせると， 無細胞セメント質においては, むしろ通常の領域 より石灰化度の低い有機成分に富んだ部分が成長 線の一部を形成しており，脱灰切片のへマトキシ リン・エオジン染色, ならびにアザン染色で色素 にほとんど染まらない明調なラインがその部分に 相当する可能性もあるように思われる。

脱灰切片を無染色のままで観察した後，その同 一切片にへマトキシリン・エオジン染色を施して 観察し，それらの所見を比べて，光線の透過性と そのラインの染色性の関係について検討してみる と, 光線の透過性の低い暗調なラインは, へマト キシリンに染色される同じく暗調なラインに一致 し，また，光線透過性がそれよりやや高い明調な ラインは, へマトキシリンにほとんど染まらない, 同じく明調なラインにほぼ一致することが確かめ られた。もちろん, 光線の透過性の観察に用いた 脱灰切片は研磨標本の場合よりはるかに薄い標本 であるが，できるかぎり切片の最表面に焦点を合 わせて観察を行い参考とした。この所見を硬組織 におけるへマトキシリン・エオジン染色の染色性 に関する従来の見解に当てはめて判断すると, 光 線透過性の高いラインは, 少なくとも透過性が低 いラインよりも有機成分が多く，それによって均 質な構造を示しているのではないかとも思われ る。

脱灰切片に PAP 鍍銀染色 (変法) を施して観察 を行うと，銀に黒染している暗調な線条の構造物 と，銀にほとんど染まらない明調な線条の構造物 からなる多数の微細な成長線様の構造物が認めら れる。鍍銀染色において黒染する部分は，そこに 銀粒子が付着する間陌があることを示すものであ ク，また，その場に銀を還元する物質が多く存在 すればするほど, 黒くなることが知られている ${ }^{61 。}$ 水城 ${ }^{22}$ は PAP 鍍銀法を用いて歯槽骨の線維骨に 見られるシャーピ一線維について観察を行い, 線 維骨内のシャーピ一線維の未石灰化部は, 好銀性 が増加していると述べている。このような PAP 鍍銀染色の特徴や水城の所見などを参考としてみ 
た場合には，無細胞セメント質において PAP 染 色で銀に黒染される成長線の暗調部は, 銀に染色 されない明調部に比べてやや石灰化度が低くなっ ているシャーピー線維の部分であることになり， それらが横に連続して成長線の一部を形成してい

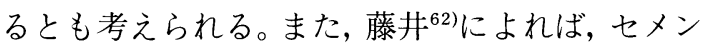
卜質に見られるシャーピー線維は，未石灰化のま まか，極軽度に石灰化したままであるといい，ま た，多くの場合，封入後，時間の経過に従って石 灰化するか, 石灰化が増すことはまれであると述 べている。また，無細胞セメント質では，シャー ピー線維も全般的に石灰化が良いとする見解もあ る ${ }^{19)}$ が, 個々のシャーピ一線維の束のうち, 石灰化 度が辺縁部より低い, ${ }^{6,7,13,32,41,63)}$ とされている中軸 部の銀親和性は高い傾向が見られる。このことか らも本切片において微細な成長線を構成している ラインのうち, 暗調部は明調部より石灰化の程度 が低い部分である可能性が高いといえる。

脱灰切片においては，これまで述べた微細な成 長線と異なって, かなりそれより幅が広く, 明暸 なものが 2 〜 本程度観察され，前述したように この部分を境としてシャーピ一線維が途切れた $\eta$, 強く屈曲するなどの状態が見られる。この成 長線は, 脱灰へマトキシリン・エオジン切片では ヘマトキシリンに濃染し, 同一切片にアザン染色 を施した場合には，色素にほとんど染まらない幅 の広いラインとなっている。また, PAP 鍍銀染色 切片では，特に明調な幅の広いラインが見られる ことがあり, CMR でも同程度の数のX線透過度 が低いラインが見られる。これらの成長線はその 出現状態や形態的特徵から，一種の成長線である と思われる。この成長線は, 脱灰へマトキシリン・ エオジン切片でへマトキシリンに染色され, PAP 染色では銀に染色されず，X線透過度が低いこと などから, 石灰化度の高い成長線である可能性が 高く，また，この成長線がアザン染色でほとんど 染色されないのは, その部の石灰化が艺進した結 果，脱灰後はそこに色素粒子が付着できないほど 広い間陌が生じたためと思われる。したがって， 前述したように，この成長線は骨の休止線あるい
は細胞セメント質 (第二セメント質)の成長線 (層 板間層）に類似したものであり，この点からも無 細胞セメント質に見られる特有の微細な成長線と は構造と性格を異にするものであると思われる。

Armitage $^{7)}$ は, 無細胞および有細胞セメント質 は，どちらも成長線によって層に分けられている が，この成長線はセメント質が周期的に形成され るものであることを示しており，また，成長線は 光学顕微鏡観察用に脱灰した標本で最もよく確か められると述べている。さらに，この成長線は超 微細構造のレベルでは同定するのが困難であると も述べている。そのようなことから, 従来の無細 胞セメント質の成長線に関する研究では, 透過電 子顕微鏡による観察像は示されていない。著者は, 未脱灰超薄切片に切片上でウランと鉛の二重電子 染色を施して, 透過電子顕微鏡で観察を行った結 果, 電子密度の高い部分と低い部分とからなる層 が交互に配列して，成長線様の形態をなしている 状態を比較的明瞭に認めることができた。この成 長線様の構造物はその幅, 間隔とも光学顕微鏡で 認められる微細な成長線とほぼ一致するものであ る。これと同様の成長線と思われるものが, 先に 述べたように, 未脱灰未染色超薄切片においても 観察され，この場合には，成長線は結晶の沈着度 の差によって出現しているが，この未染色切片で は成長線はきわめて認めにくい状態であった。し かし，電子染色を施して観察を行うと，比較的数 多くの成長線が認められるようになる。これは, 後述するように，やや酸性に傾いている染色液に よって結晶が染色中にある程度溶解消失するとと もに，そこに存在していた有機成分が染色される ことによって, 成長線が比較的明瞭に出現するよ うになったとも考えられ，無細胞セメント質に見 られる微細な成長線は, 結晶の沈着密度の差（石 灰化度の差) のみに起因する成長線ではないよう にも思われる。一條ら ${ }^{22}$ は, 正常なエナメル質の未 脱灰切片を透過電子顕微鏡で観察すると, 切片上 で酸腐蝕を行わないかぎり，未処置の状態のもの ではほとんど小柱の横紋構造は観察されないが, う蝕によって侵食されたエナメル質では, 酸腐蝕 
標本と同様，石灰化の良好な部分の結晶がより溶 解減少し，横紋構造が明瞭に出現すると述べてい る。未脱灰のまま工ポキシ樹脂に包埋し，それら の試料について超薄切片を作製し，その切片上で 電子染色を行った場合には, pH のやや低い染色 液によって染色中に結晶成分がかなり溶解消失す る。その量は切片の厚さ，包埋条件ならびに染色 条件によって多少異なると思われるが，未脱灰超 薄切片に切片上で電子染色を施した場合には，一 條ら ${ }^{22}$ がエナメル小柱の横紋で示しているよう に，石灰化度が低い部分の方が，染色後において は，結晶がかえって多く残存し，また電子密度が 高い状態となっていると思われる。もともと石灰 化度が高く, 結晶が多く存在していた部分は結晶 が密で，結晶間隙への包埋用の樹脂の浸透が少な く，また結晶間隙の有機成分も同様に少ないもの と思われるのに対して，石灰化度の低い部分は結 晶間隌がそれより広く，したがって樹脂の浸透と 有機成分の量も多いと考之られる。このような部 位が染色液にさらされた場合には，おそらく，結 晶が密な石灰化度の高い部位にある結晶は，樹脂 や有機成分による被覆が少ないために，かえって 多くの結晶が溶解消失し，樹脂や有機成分によっ て周囲が被覆されている石灰化度の低い部分より もそこに残存している結晶の量が染色後は少なく なることがあると思われる。それに加えて，有機 成分の多い分だけ，石灰化度の低い部位は，染色 液に染まり，多く残存している結晶や樹脂ととも に，電子密度がむしろ高くなる傾向があるように 思われる。そのようなことから, 著者が観察を行っ た無細胞セメント質の成長線においては，未脱灰 超薄切片に切片上で電子染色した切片で，電子密 度が高くなっているラインの部分は, 電子密度が 低いラインの部分より結晶成分も多く残存してお ク, 本切片で電子密度の高いラインは低いライン より，もともと石灰化度がわずかに低く，有機成 分もやや多くあった部分である可能性があると思 われる。また，シャーピー線維は辺縁部のほうが 中軸部より石灰化度が良いとされてお $\eta$ 6,7,13,32,63), 本超薄切片においても, シャーピー線
維の辺縁部の電子密度が中軸部より低下している 状態が見られることは，この関係を裏付けている と考之られる。以上のような透過電子顕微鏡所見 と光学顕微鏡ならびに走査電子顕微鏡所見を総合 してみると，無細胞セメント質に見られるこれら の微細な成長線は, 石灰化度の差によって生ずる 可能性もあるが，それはごくわずかの差であって， それ以外に有機成分の差による影響もかなり強い ように思われる。

電子密度が高いラインも，また電子密度が低い ラインも，電子密度が高いシャーピー線維を通過 する部分では，同一ラインでもそれに伴って電子 密度がわずかに高くなる傾向が見られる。このよ うに, この成長線はシャーピー線維の石灰化度や 有機成分の量の変動や構造変化に影響を受ける状 態が見られることからも，きわめてシャーピー線 維との関連性が強いものであるといえる。

脱灰切片にへマトキシリン・エオジン染色を施 して無細胞セメント質の最表層部を観察すると, ヘマトキシリンに染色されている石灰化前線の部 分が, 個々のシャーピー線維の単位で波状の湾曲 を呈している状態が認められる。この波状の形態 は，前述した微細な成長線に見られる個々の波状 の湾曲と一致するものである。Schroeder ${ }^{6}$ は, 無 細胞セメント質 (無細胞性外部性線維セメント質) の表面を走査電子顕微鏡で観察し，石灰化前線に おけるシャーピー線維の形態は，ドーム状をして いることを示している。これらのことからも，無 細胞セメント質に見られる微細な成長線の形態形 成は，石灰化前線の形態を反映し，直接あるいは 間接的にそれと深い関わりを持っているものと思 われる。また，最表層の一層がこのようにへマト キシリンに濃く染まる層（暗調な層）をしている 場合と，それよりへマトキシリンに対する染色性 が低く，エオジンに淡染する明調な層が見られる 場合とがある。この明調な層, あるいは暗調な層 がそれぞれ隣接のものと連続して明調なライン， あるいは暗調なラインを形成している状態も見ら れる。アザン染色切片では，七メント質の表層部 が，深層部に比べて全般的にアゾカルミンに染色 
される傾向が見られるため, 最表層の石灰化前線 に相当する部分もアゾカルミンに染まり，その部 分がシャーピー線維ごとの単位で波状の湾曲を呈 している。また，アザン染色切片においても，最 表層部にアゾカルミンに濃く染まる層とアゾカル ミンに淡染する層とが見られ，それらが互い違い に並んで無細胞セメント質の全域に見られる通常 の微細な成長線と同様の形態を示している状態が 見られる。また，これらのラインは，セメント質 の梁層側に向かうに従って, 通常の成長線と同様 染色性が低くなっている傾向が見られる。した がって，へマトキシリン・エオジン染色切片とア ザン染色切片で観察されるこれらの所見から, 無 細胞セメント質に見られる微細な成長線は，セメ ント質の形成時に，その直後からそこに形成され る可能性があるものと思われる。しかし，特にア ザン染色で見た場合，その場の染色性の変化に 伴って成長線の染色性も変化していることから, ある程度は形成後の時間の経過とともに, 成長線 の構造や性状も変化するものと考えられる。

山下ら ${ }^{12)}$ は無細胞セメント質の構造的特徵につ いて観察を行っているが，特に歯根が大幅に露出 しているような標本においては，無細胞セメント 質に見られる比較的明暸な成長線が，歯頸側に向 かうに従って開大し，そこに細菌などが侵入して いる像を示している。前述したように著者が観察 を行っている $2 \sim 3$ 本程度の割合で無細胞セメン 卜質に出現する石灰化の程度が高いと思われる明 瞭な成長線も，その部で広く離開し，亀裂が生じ ている場合も認められる。この成長線は特に歯頸 部にいたって，セメント質表面に移行的に終わっ ているような場合には，そこから離開や亀裂が始 まっていることが多い。もちろん，切片の作製時 に人工的に離開や亀裂が拡大した可能性が強い が，この成長線は石灰化度が高い部分であると考 えられることから, 特に歯根部が露出していて脱 灰されたような場合には，下地となっている有機 成分がもともと少ないうえに，シャーピー線維が その部分で石灰化の克進によって損傷を受けて弱 くなっている可能性も高く, またその部でシャー
ピー線維が中断しているような場合には，特にこ の成長線の部分の結合が弱くなっていることも十 分考えられる。したがって，生体中において根面 う蝕などが生じた場合には，このような成長線の ラインに沿ってう蝕が進行し，それらに侵入門戸 を与えることになる可能性も高いと思われる。こ のような状態が生ずることは，すでに象牙質の成 長線においても報告がなされている12,21,24 30)。本 来，セメント質の機能は歯を歯槽骨に固定する役 割を持っている ${ }^{1 \sim 4,7,13,14) か ゙ ， こ の よ う な セ メ ン ト ~}$ 質の成長線に沿った剥離や構造的崩壊が，歯根膜 と接している根尖側のセメント質の領域にまで波 及した場合には，この部におけるセメント質の支 持機能が局所的に低下寸ることは免れないと思わ れる。一方，無細胞セメント質に出現する微細な 幅と間隔を有する特有の成長線は，著者が考察し たように，石灰化度の差にもよるが，むしろ有機 成分の沈着あるいは残存状態に周期性があって, それがこの成長線の出現にかなり影響しているよ うに思われ，有機成分の多い成長線の部分がある とすれば，それだけその部のシャーピ一線維が石 灰化の極端なえ進などによって損傷を受けること が少ないものと思われる。従来から, 無細胞セメ ント質は細胞セメント質より石灰化が良いという 見解 ${ }^{10,19,64)}$ や無細胞セメント質のシャーピー線維 は石灰化度が高いという報告 ${ }^{19)}$ も見られるが, シャーピー線維は一般にその中軸部の石灰化が低 いともいわれており，その場合には，中軸部とこ の有機成分の多い成長線の部分とが石灰化硬組織 のなかにあっても，シャーピ一線維にある程度の 弾性と適当な硬さを与えることができ，シャ一 ピ一線維本来の歯の固定という機能を果たすのに 適しているとも考えられる。

石灰化硬組織のなかでも，エナメル質は発生過 程や構造ならびに無機成分と有機成分の含有比 が，象牙質，セメント質ならびに骨組織などと異 なっている ${ }^{4,7)}$ 。象牙質，セメント質ならびに骨組 織は中胚葉性の組織で，基本的にはコラーゲン線 維を下地としてそこに無機の結晶が沈着してい る。下地のコラーゲン線維は主としてそれらの組 
織の表面（形成面）に平行に配列する基質線維で あるが，それにそれぞれの組織の機能や発生に関 連して，コルフの線維あるいはシャーピ一線維な どがそこに埋め込まれ，同時に下地となっている 場合もある。セメント質のうちでも，細胞セメン 卜質は，象牙質ならびに骨組織と同様に，基質線 維がその下地の大半を占めており，主としてセメ ント芽細胞によって形成され，また石灰化も行わ れている。しかし，セメント質のうちでも，いわ ゆる典型的な無細胞セメント質においては, シャーピー線維が大半で, 基質線維がごくわず か ${ }^{1,2,4,6)}$ となっているため, シャーピ一線維が下地 の線維をなしていることになる。またこのシャ一 ピー線維は extrinsic fiber ${ }^{6,13,18)}$ などと呼ばれ，歯 根膜の線維芽細胞などによって形成されたもので あると考えられ，下地の大半をなす線維の由来が 細胞セメント質などと異なるものであるといえ る。このように，無細胞セメント質は有細胞セメ ント質と下地となる線維成分の種類, 構成状態, 由来など構造的違いと, 形成細胞やその細胞の役 割分担の違いなどがあり，このことが無細胞セメ ント質のシャーピー線維上に出現する特有の微細 な成長線の形成と何らかの関わりがあると推察さ れることから，今後は発生学的ならびに細胞学的 な立場から，この成長線の由来をさらに検討する 必要があると思われる。

\section{V. 結}

ヒトのセメント質の機能を形態学的な立場から 究明する研究の一端として, 無細胞セメント質に 見られる成長線の構造について光学顕微鏡, microradiogram (CMR), 走査ならびに透過電子顕 微鏡を用いて観察を行った結果，以下のような結 論を得た。

1. 無細胞セメント質には, 幅平均 $0.5 \mu \mathrm{m}$ 前 後の微細な成長線が多数観察される。

2. 無細胞セメント質に見られる微細な成長線 は，シャーピー線維が豊富で，それらが平行に整 然と配列している領域において明瞭に観察され る。
3. また，この微細な成長線は，個々のシャー ピー線維の単位で湾曲が見られ，それらが連なっ て，一本の成長線を形成している。

4. シャーピー線維の単位で出現する成長線の 湾曲は，石灰化前線の形態に一致している。

5.このように, 微細な成長線は, シャーピー 線維上に出現する無細胞セメント質特有の構造物 であり，その部のシャーピー線維の構造や配列状 態と密接な関連性があるように思われる。

6. また，無細胞セメント質に見られる微細な 成長線は，石灰化度の差によって出現する状態も 見られるが，その差は軽微であることから，そこ に存在する有機成分の差もその出現に関連してい るように思われる。

7. 無細胞セメント質には，この微細な成長線 のほかに, 幅が広く，しかも比較的明瞭な成長線 が $2 \sim 3$ 本程度観察される。この成長線は, 通常 のセメント質の部分に比べて石灰化度が高く, 細 胞セメント質に見られる成長線（層板間層）に相 当するものであると考えられる。

8. また，この成長線は，それに沿って亀裂が 生じている場合などもあり，構造的に弱く，また 根面う蝕の際には細菌の侵入門戸となる可能性も あると思われる。

\section{謝辞}

稿を終わるに臨み，終始ご愁篤なるご指導とご校閲 を賜りました本学歯学部口腔解剖学第一講座の 山下靖雄教授に深甚なる感謝の意を表します。また， 本研究に際しご援助，ご協力をいただきました口腔解 剖学教室の諸先生に厚く御礼申し上げます。

なお, 本研究の一部は第 35 回歯科基礎医学会総会 (平成 7 年 9 月 23 日，東京）にて発表した。

\section{文献}

1）山下靖雄：歯周組織の解剖・組織学. 石川 烈 歯周病学, 東京, 1996, 永末書店, 3-6.

2）陳 妙卿：ヒトセメント質における基質線維の 基本構造に関する観察。口病誌 $54: 635-675$, 1987.

3）山下靖雄，一條 尚：歯周組織の形態と機能(1). Dental Diamond 11(2): 54-57, 1986. 
4）藤田恒太郎：歯の組織学. 東京, 1957, 医歯薬出 版, 133-146, 159-171.

5）井上昌幸：歯根セメント質の組織学的構造に現 れた機能的影響について。補緅誌 4:124-146， 1960 .

6) Schroeder, H. E. : The Periodontium. Germany, 1986, Springer, 23-129.

7) Armitage, G. C. : Cementum. Bhaskar, S. N., Orban's Oral histology and embryology, 10th ed. St. Louis, 1986, Mosby, 175-197.

8) Schmid, P.: Polarisationsoptische Untersuchungen der Faserstrukturen des Zementes atypisch belasteter Zahne. Acta. Anat. 49 : 236251, 1962.

9) Kronfeld, R. : The Biology of Cementum. J. Am. Dent. Assoc. 25 : 1451-1461, 1938.

10）小沢英浩：歯牙硬組織の微細構造. 細胞 $4(8)$ : 2-24, 1972 .

11）石川梧朗：口腔病理カラーアトラス. 東京, 1983, 医歯薬出版.

12）山下靖雄, 一條 尚：歯根面の解剖学的形態に ついて. 日本歯科評論 $608: 70-85,1993$.

13) Ten Cate, A. R. : Periodontium. Oral Histology : Development, structure, and function, 3rd ed. St. Louis, 1989, Mosby, 244-247.

14）三枝 博, 島村昭辰：口腔組織学. 福岡，1975, 福岡歯科大学出版部, 95-101.

15) Shimamine, T. : Das sekundare Zement. Deutsche Zhk. $13: 3-65,1910$.

16）日本解剖学会：解剖学用語. 改訂 12 版, 東京, 1992, 丸善, 251 .

17) Weidenreich, F.: Uber die Beziehungen zwischen Zahn, Alveolarwand und Kiefer. Z. Anat. Entw.-gesch. 83, 1926.

18）雨宮 璋：歯根膜, セメント質の微細形態と病 変. 細胞 15(11)：2-6, 1983 .

19）小澤英浩：歯の形成と構造. 須田立雄, 小澤英浩, 高橋栄明, 骨の科学. 東京, 1980, 医歯薬出版, 102-105, 110-117.

20) Furseth, R. : The fine structure of acellular cementum in young human premolars. Scand. J. Dent. Res. 82 : 437-441, 1974.

21）王 博賢：蔈蝕による歯頸部象牙質の構造変化 に関する観察一歯頸部象牙質の構造と齲蝕の進 行方向の関連性について一. 日歯保誌 34 (2): 663-699， 1991.

22）一條 尚, 山下靖雄：エナメル質微細構造と齲 蝕像について. 須賀昭一, 石井俊文, 䶚蝕感受性, 東京, 1976, (財)口腔保健協会, 94-116.

23）須賀昭一：エナメル質形成の観点から見たエナ メル質表層の構造と組成. 須賀昭一，石井俊文, 龇蝕感受性, 東京, 1976, 財)口腔保健協会, 5-42.

24）田熊庄三郎，松宮誠一：図説口腔病理学. 東京,
1986, 医歯薬出版， 139-163，200-249.

25）石川梧朗, 秋吉正豊：口腔病理学. 京都, 1983, 永 末書店，208-249.

26) Leon, M. Silverstone and M. Johs, Hicks : The structure and ultrastructure of the carious lesion in human dentin. Gerodonics, 1 : 185-195, 1985.

27）二階宏昌，岡邊治男編：歯学生のための病理 学; 口腔病理編. 東京, 1990, 医歯薬出版.

28) Schupbach, P., Guggenheim, B. and Lutz, F. : Human Root Caries: Histopathology of Advanced Lesions. Caries Res. 24:145-158, 1990.

29）松井隆弘：象牙質特に Ebner 氏層板，Andresen 氏横線，Mummery 氏象牙質紋理，Owen 氏外形 線, Richter 氏球間網等に就いて。歯科学報 47 (7) : 1-17, (8):26-39, (10) : 1-15, (12) : 17-34, $1942,48(1): 1-13,1943$.

30) Schupbach, P., Guggenheim, B. and Lutz, F. : Histopathology of Root Surface Caries. J. Dent. Res. 69: 1195-1204, 1990.

31）渡辺緯津子：七下下顎歯槽骨における休止線な らびに接合線の構造上の特徵に関する観察。口病 誌 $52: 397-437,1985$.

32）水城春美：ヒト下顎歯槽骨内壁における線維骨 の構造に関する組織学的観察。口病誌 $46: 65-$ 104, 1979 .

33) Philipson, B. : Composition of cement lines in bone. J. Histochem. Cytochem. 13:170-281, 1965.

34) Weidenreich, F. : Das Knochengewebe. Mollendorff, W. V., Handbuch der mikroskopischen Anatomie des Menschen, Band 2 ii. Berlin, 1930, Springer, J., 391-520.

35) Frasca, P. : Scanning-electron microscopy studies of 'ground substance' in the cement lines, resting lines, hypercalcified rings and reversal lines of human cortical bone. Acta. Anat. 109 : 115-121, 1981.

36) Castanet, J. : New data about cement lines in bone. Calcif. Tissue Int. 31 (Suppl) : Abstract 47, 1980 .

37）松尾 朗, 矢嶋俊彦：セメント質の線維性基質 と層板構造. 日歯周誌 $32: 140-149,1990$.

38) Yamamoto, H., Masuda, M., Toeda, K. and Suzuki, K. : Microradiographic and histopathological study of the cementum. Bull. Tokyo Med. Dent. Univ. 9 : 141-150, 1962.

39）桐野忠大, 一條 尚, 小野 毅, 根岸伸行, 小沢 幸重, 脇田 稔, 山下靖雄, 鈴木駿介, 後藤仁敏： ヒトセメント質の基質線維について。ロ病誌 $39: 821,1972$.

40）松尾 朗，矢嶋俊彦：セメント層板と成長線の 
光学顕微鏡, 走査電子顕微鏡とマイクロラジオグ ラフィーによる比較観察。歯基礎誌 $34: 171-$ 180,1992

41) Furseth, R. : A microradiographic, light microscopic and electron microscopic study of the cementum from deciduous teeth of pigs. Acta Odont. Scand. $28: 811-831,1970$.

42) Hopewell-Smith, A. : Concerning human cementum. J. Dent. Res. 2: 59-76, 1920.

43）一條 尚, 山下靖雄, 小野 毅, 脇田 稔, 鈴木 駿介, 小沢幸重, 後藤仁敏：象牙質の基質線維と 象牙細管の構造について。病誌 42:75-139, 1975.

44) Yamashita, Y. and Ichijo, T. : Comparative studies on the struture of the ameloblasts. Suga, S. ed, Mechanisms of tooth enamel formation, Tokyo, 1983, Quintessence, 91-107.

45）黄 世英：七卜象牙質表層部における象牙細管 の構造に関する観察。口病誌 $52: 438-468$, 1985.

46）童 平：大臼歯にみられる第二象牙質の構造 に関する観察。日歯保誌 37：336-368，1994。

47) Selvig, K. A. : The fine structure of human cementum. Acta Odont. Scand. 23:423-441, 1965.

48) Furseth, R. and Johansen, E. : A microradiographic comparison of sound and carious human dental cementum. Archs. Oral Biol. 13 : 1197-1206, 1968.

49）東 与光, 青山晨亘: Oral radiology. 東京, 1978, 日本医事新報社.

50）胡 継民：ヒト永久歯のセメント質内 Sharpey 線維の微細構造的研究一咬合と加齢に伴うにつ いて一。 口科誌 42：1-15, 1993.

51）西川英次：ヒ卜下顎歯槽骨における層板骨の基 本構造と石灰化度の差に関する観察。口病誌 $51: 238-279,1984$.

52) Okada, M., Mimura, T. and Ishida, T. : The hematoxylin-stainability of decalcified dentin and the calcification. Proc. Japan Academy $35: 47-52,1959$.

53）須賀昭一：染色法. 須賀昭一，田熊庄三郎，佐々 木哲編, 歯の研究法, 東京, 1973, 医歯薬出版, 54-69.

54）大塚長康：金属とその他の無機物質. 小川和朗, 武内忠男, 森富編, 新組織化学, 東京, 1975, 朝倉書店, 655-680.

55）山下靖雄，小野 毅，鹿野俊一，一條 尚：イシ ダイの歯のエナメル質形成にともなう有機基質 の構造変化について。.エナメル質比較発生学㤠話 会記録 $1 ： 37-40,1989$.

56）桐野忠大, 一條 尚, 後藤仁敏, 小野 毅, 小沢 幸重, 山下靖雄, 脇田 稔, 鈴木駿介：ヒトエナ メル質の構造に関する走査電子顕微鏡的研究 1.エナメル小柱の形態ならびに小柱鞘と小柱間 質について。病誌 $39: 247-296,1972$.

57）佐野 豊: 組織学研究法. 東京, 1976, 南山堂.

58）頼 偉生：龋蝕による象牙質の構造変化に関す る観察。口病誌 $54: 461-489,1987$.

59）大迫正文：ラット下顎骨関節突起の発育と機能 に関する組織学的研究。口病誌 60:4-60, 1993.

60) Boyde, A. : Enamel. Berkeovitz, B. K. B., Boyde, A., Frank, R. M., Hohling. H. J., Moxhan, B. J., Nalbandian, J. and Tonge, C. H. ed., Teeth. Germany, 1987, Springer, 309-473.

61）藤田尚男, 藤田恒夫：標準組織学総論. 第三版, 東京, 1988, 医学書院.

62）藤井仁毅：セメント質の石灰化像。歯学 57 ： 570-592, 1969.

63) Boyde, A. and Jones, S. J. : Scanning electron microscopy of cementum and Sharpey fibre bone. Z. Zellforsch. 92: 536-548, 1968.

64) Soni, N. N., Van, Huysen, G. and Swenson, H. M. : A microradiographic and X-ray Densitometric Study of Cementum. J. Periodont. $33: 372-378,1962$.

\title{
付図記号説明
}

\author{
$\mathrm{AC}$ ：無細胞セメント質 $\mathrm{D}$ ：象牙質 PM：歯根膜 SF：シャーピー線維
}

\section{付図説明}

光学顕微鏡写真は撮影倍率, 電子顕微鏡写真は写真倍率を示す。 
困 1 ヘマトキシリン染色研磨標本。無細胞セメント質には, 微細な成長線様の構造物が見られるが，これらの微 細な成長線は必ずしも特異的にへマトキシリンに染色されている状態ではない。しかし，この標本において矢 印で示したラインは，へマトキシリンに染色されている（×100）。

図 2 脱灰切片（へマトキシリン・エオジン染色）。へマトキシリンに染まる暗調なラインとエオジンに淡染する 明調なラインが交互に配列して, 微細な成長線を形成している。また，なかにはへマトキシリンに濃染するや や幅の広いライン (矢印) も認められる $(\times 200)$ 。

図 3 脱灰切片 (ヘマトキシリン・エオジン染色)。困 2 と同様に微細な成長線が多数認められる $(\times 200)$ 。

図 4 脱灰切片(へマトキシリン・エオジン染色)。無細胞セメント質の表層部の拡大。石灰化前線もシャーピ一線 維の単位で波状の湾曲を呈している。また，石灰化前線付近が，へマトキシリンに染まる場合とエオジンに淡 染する場合とがあり，そのような層が最表層部付近ですでに交互配列しているような状態も見られる（矢印） $(\times 250)$ 。

図 5 脱灰切片（へマトキシリン・エオジン染色）。ヘマトキシリンに染まるラインとエオジンに淡染するライン とからなる微細な成長線のほかに，へマトキシリンに濃染する幅の広いライン（矢印）も認められ，そのライ ンの一部に亀裂が生じている（※）（×100）。

図 6 脱灰切片（アザン染色）。微細な成長線のほかに，色素にほとんど染まらない幅の広い成長線（矢印）が観 察され，図 5 の切片の場合と同様に，このラインに沿って亀裂が生じている（※）（×100)。

図 7 脱灰切片 (アザン染色)。アゾカルミンあるいはアニリン青に染まる暗調なラインとそれらの色素にあまり 染まらない明調なラインからなる多数の微細な成長線が観察される。アニリン青に染まるシャーピー線維が 多く見られ，しかもそれらの束が不明瞭で配列も乱れているような部位では, 成長線もやや不明瞭となってい る $(※)(\times 200)$ 。

図 8 脱灰切片 (アザン染色)。無細胞セメント質表層部の拡大。石灰化前線は, シャーピ一線維の単位で歯根膜 側に向かって凸湾した形態を呈している。石灰化前線付近において，すでに成長線様の構造物 (矢印) が観察 される $(\times 200)$ 。

図 9 脱灰切片（A：ヘマトキシリン・エオジン染色，B：アザン染色）。同一切片にヘマトキシリン・エオジン染 色とアザン染色を施して, 同一ラインの染色性を比較したもの。通常の微細な成長線においては, へマトキシ リン染色される暗調なラインが, アザン染色でも色素に染まる暗調なラインと一致し, エオジンに淡染する明 調なラインは，アザン染色でも色素にあまり染まらない明調なラインとなっている。しかし，セメント・象牙 境やへマトキシリンに濃染する幅の広い成長線は, アザン染色で色素に染まらない明調な部分となっている (矢印) $(\times 200)$ 。

図 10 研磨標本 (無染色研磨標本)。無細胞セメント質の領域には, 光線透過性の差によって微細な成長線様の構 造物が不明暸ながら観察される $(\times 160)$ 。

困 11 研磨標本 (酸腐蝕研磨標本)。セメント質表面に対してほぼ直交する方向に配列しているシャーピー線維の 束の輪郭が認められる (矢頭)。また, 個々の成長線は必ずしも直線的でなく, 細かい波状の湾曲が見られる (矢印) $(\times 160)$ 。

図 12 研磨標本 $(\mathrm{A}$ : 脱灰無染色研磨標本, $\mathrm{B}$ ：脱灰へマトキシリン染色研磨標本)。脱灰した研磨標本に染色を行 わないで, 光線透過性の差によって出現する成長線と, へマトキシリンに染色を施した場合に出現する成長線 を同一切片にて比較したもの。無染色標本で暗調に見えるラインは, 染色標本でへマトキシリンに染まる暗調 なラインと一致している。また, 無染色標本の明調ラインは, 染色標本でも染色性の低い明調ラインと一致し ている $(\times 200)$ 。

困 13 脱灰切片 $(\mathrm{A}$ : 無染色, B : ヘマトキシリン・エオジン染色)。脱灰切片に染色を行わないで, 光線透過性の 差によって出現する成長線と, へマトキシリン・エオジン染色を施した場合に出現する成長線を同一切片上で 比較したもの。無染色切片で暗調なラインは, へマトキシリン・エオジン染色切片ではへマトキシリンに染ま る暗調ラインと一致し, 無染色切片で明調なラインは, ヘマトキシリン・エオジン染色ではへマトキシリンに ほとんど染まらない明調なラインと一致している $(\times 200)$ 。 
図 14 研磨標本 (CMR 像)。X 線透過性の低いライン (LL) と高いライン (DL) が不明瞭ながらごくわずかに観 察される $(\times 100)$ 。

図 15 脱灰切片（へマトキシリン・エオジン染色）。へマトキシリンに濃く染色される暗調なラインと，へマトキ シリンに染色されず，エオジンに淡染する明調なラインからなる微細な成長線様の構造物が明瞭に観察され る $(\times 200)$ 。

図 16,17 脱灰切片 (PAP 鍍銀染色)。銀によって黒染しているラインと, 銀にほとんど染色されない明調なライ ンが平行に並んで成長線を構成している。シャーピ一線維が銀にやや濃く染まっている。成長線は個々の シャーピー線維の単位で湾曲しており，その湾曲の凸部はセメント質表面側を向いているものが多い（矢印） $(\times 250)$ 。

図 18 脱灰切片 (PAP 鍍銀染色)。微細な成長線のほかに，特に幅が広く，銀にほとんど染色されないラインも見 られる (矢印) $(\times 250)$ 。

図 19 酸腐蝕研磨面 (走查電子顕微鏡像)。酸腐蝕によってわずかに陥凹した溝状の構造物が不明瞭ながら認めら れる (矢印) $(\times 2,500)$ 。

図 20 脱有機研磨面 (走査電子顕微鏡像)。セメント質の表面にほぼ平行な方向に配列している多数の微細な溝状 の構造物が観察される $(\times 1,000)$ 。

図 21，22 脱有機研磨面(走査電子顕微鏡像)。図 20 と同様に微細な溝状の構造物が観察され，これらは波状の湾 曲を呈している状態が不明瞭ながら認められる（矢印） $(\times 1,500),(\times 2,000)$ 。

図 23 未脱灰未染色超薄切片 (透過電子顕微鏡像)。シャーピー線維に対してほぼ直交する方向に走行している電 子密度のやや高い層（々）と，低い層（ネ）が不明瞭ながら認められる。しかし，シャーピー線維の配列が乱 れているような部位では，これらの層はほとんど認められない $(\times 10,000)$ 。

図 24 未脱灰電子染色超薄切片（透過電子顕微鏡像）。電子密度の高い層（ライン）と低い層（ライン）が交互に 並んで，成長線様の形態をなしている。これらの成長線は細かい波状の湾曲が見られ，その湾曲は個々の シャーピー線維の単位で生じている。また, 湾曲の凸部はほとんどの場合, セメント質の表面側（写真上方） を向いている $(\times 5,000)$ 。

図 25 未脱灰電子染色超薄切片（透過電子顕微鏡像）。電子密度の高い層（ライン）と低い層（ライン）が交互に 並んで，成長線様の形態をなしている。これらの成長線は細かい波状の湾曲が見られ，その湾曲は個々の シャーピー線維の単位で生じている。また，湾曲の凸部はほとんどの場合，セメント質の表面側（写真上方） を向いている。また，同一成長線でも，隣のシャーピー線維に移行すると，幅，間隔ともに多少変化している 状態が見られ,ここでは, シャーピー線維が縦断されている線維に移行する際に成長線の幅がわずかに狭くな るとともに, 波状の湾曲の程度もやや強くなる傾向が見られる。成長線の幅と湾曲度の変化を示すために, ラ イン上に破線を付記した $(\times 8,000)$ 。

図 26 未脱灰電子染色超薄切片 (透過電子顕微鏡像)。電子密度の高い層（ライン）と低い層（ライン）が交互に 並んで，成長線様の形態をなしている。これらの成長線は細かい波状の湾曲が見られ，その湾曲は個々の シャーピー線維の単位で生じている。また，その湾曲の凸部はほとんどの場合，セメント質の表面側(写真上 方)を向いている。シャーピー線維のうち, 辺縁部付近は, 中軸部に比べて全般的に電子密度が低い傾向があ る $(\times 5,000)$ 。

図 27 未脱灰電子染色超薄切片 (透過電子顕微鏡像)。電子密度の高いラインも, 電子密度の低いラインも, 電子 密度の高いシャーピー線維の部分を通過する際には, 同一ラインでもその部分だけ電子密度がやや高くなる 傾向が見られる $(\times 10,000)$ 。

図 28 未脱灰電子染色超薄切片（透過電子顕微鏡像）。電子密度の高い層（ライン）と低い層（ライン）が交互に 並んで, 成長線様の形態をなしている。同一の成長線でも, 隣のシャーピー線維に移行すると, 幅, 間隔とも に多少変化している状態が見られ, ここでは, シャーピー線維が縦断されている線維に移行する際に成長線の 幅がわずかに狭くなるとともに, 波状の湾曲度もやや強くなる傾向が見られる。成長線の幅と湾曲度の変化を 示すために, ライン上に破線を付記した $(\times 16,000)$ 。 


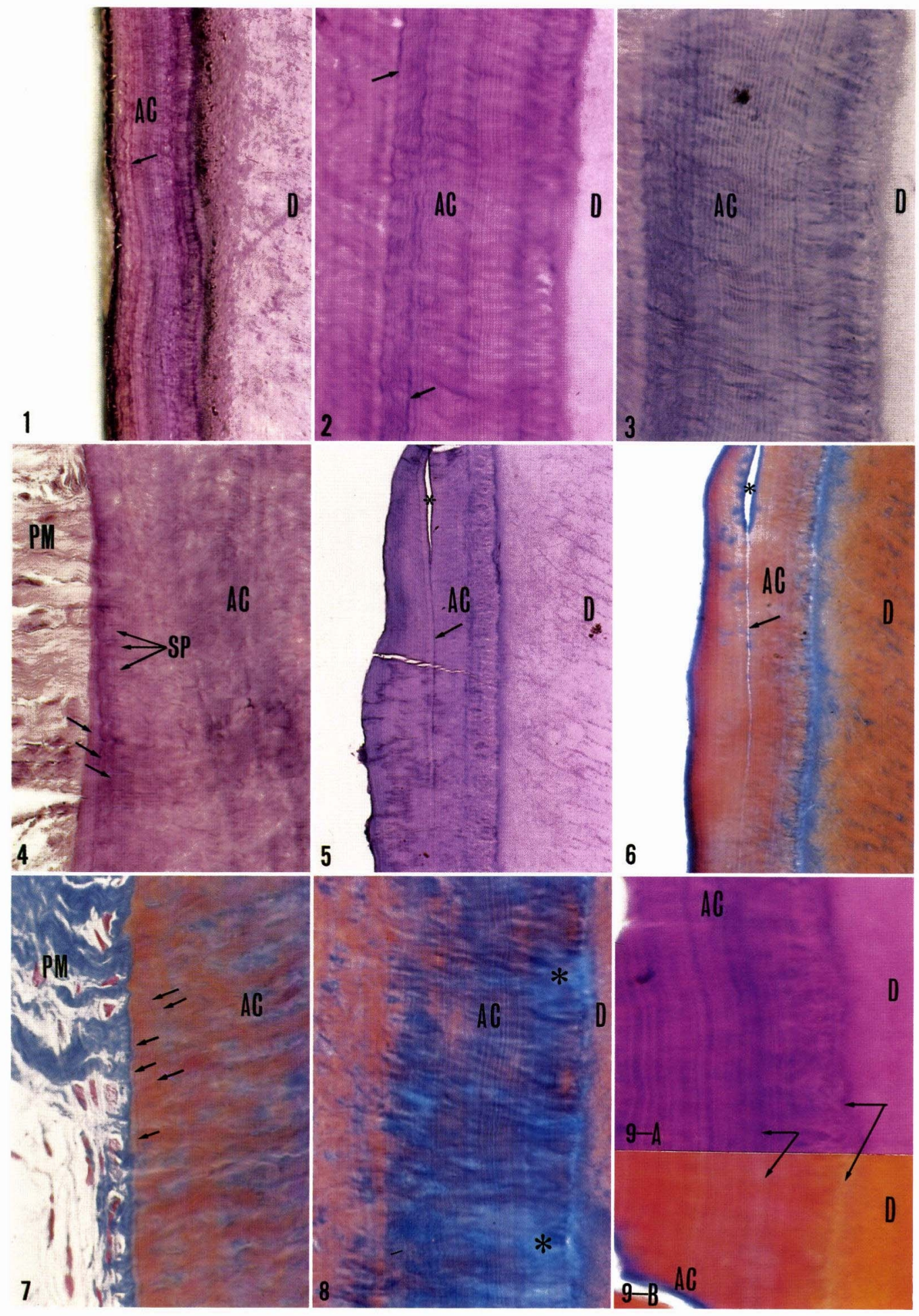



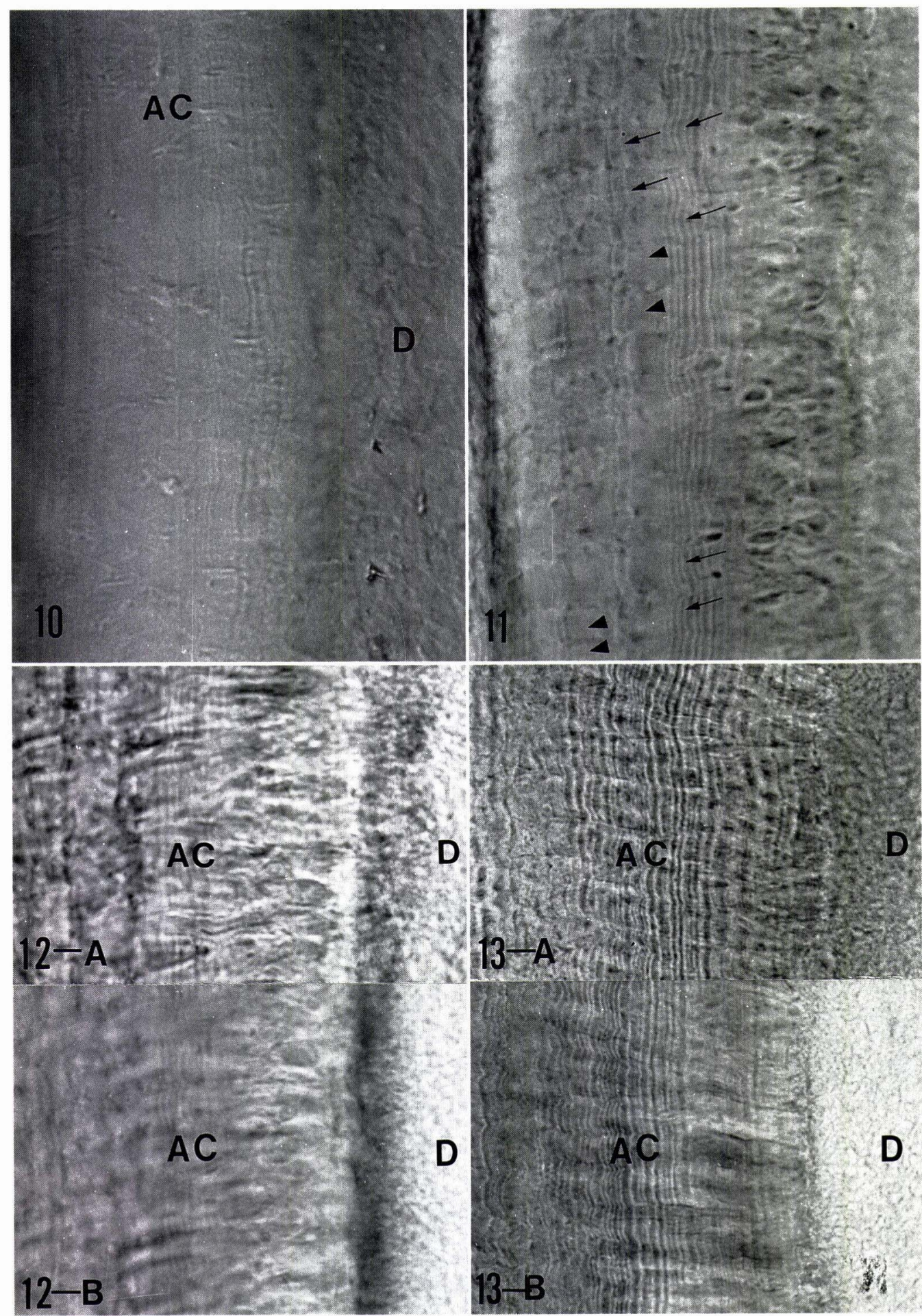

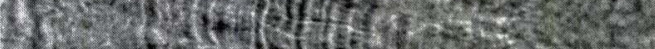

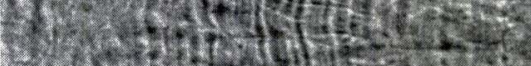

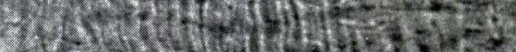

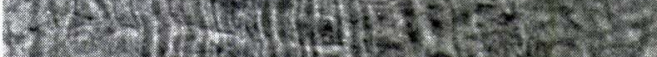

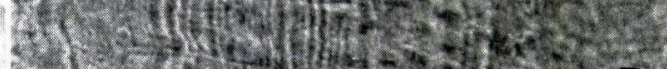

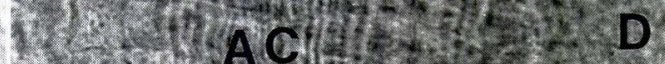

3.5. A C.

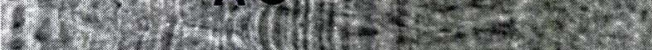

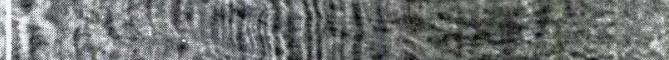

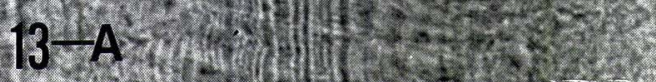

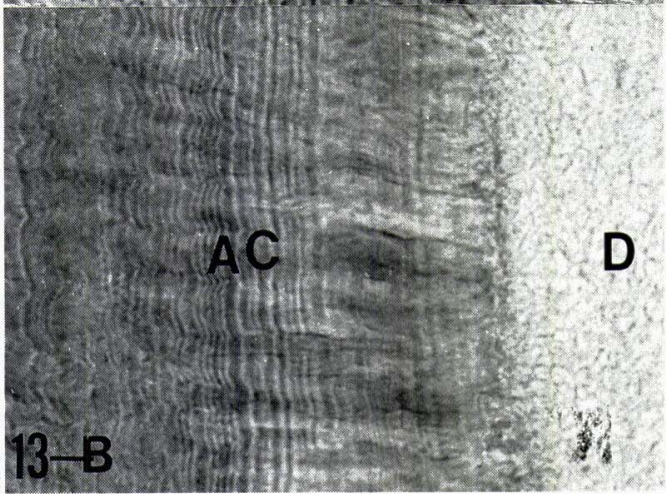




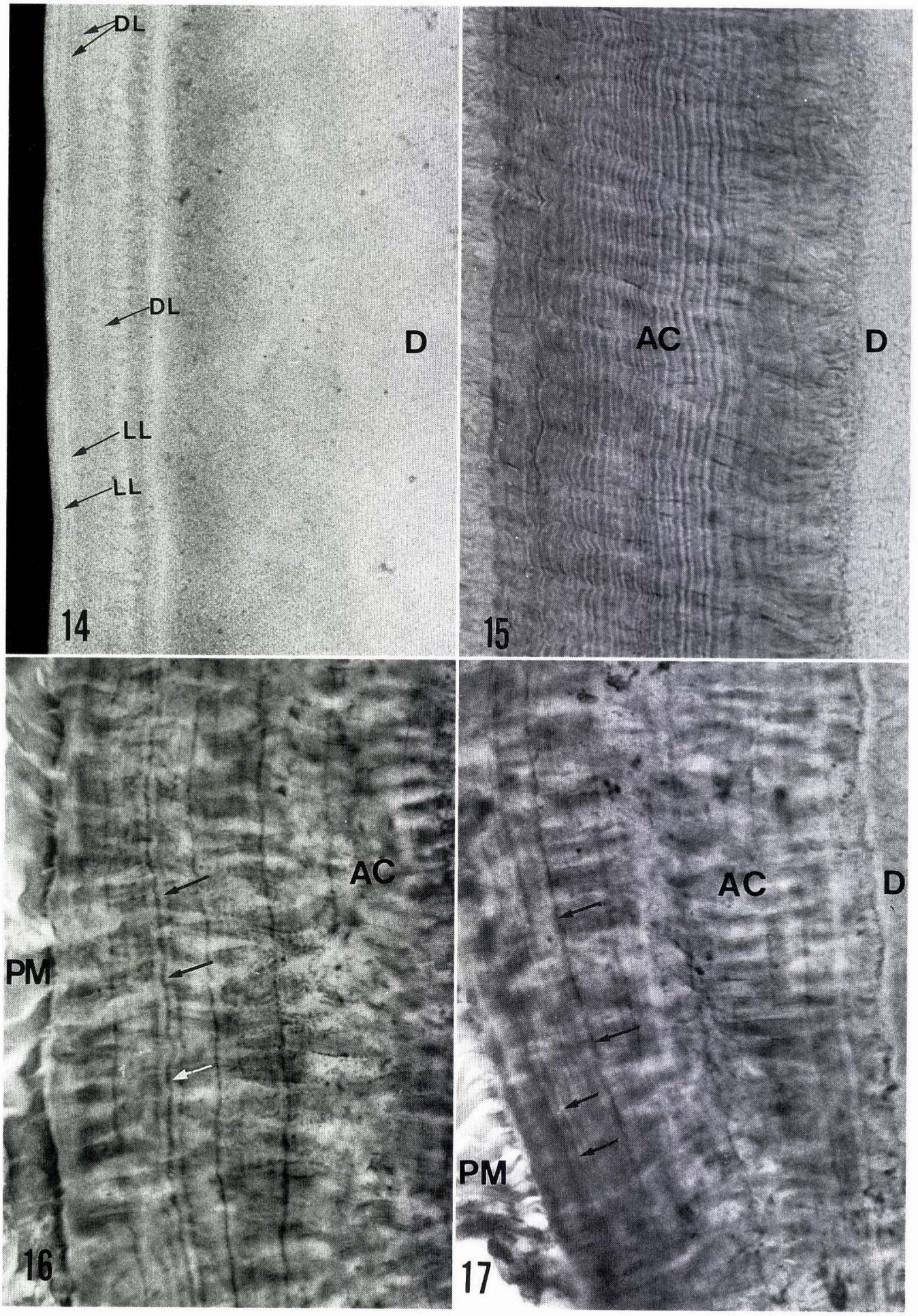



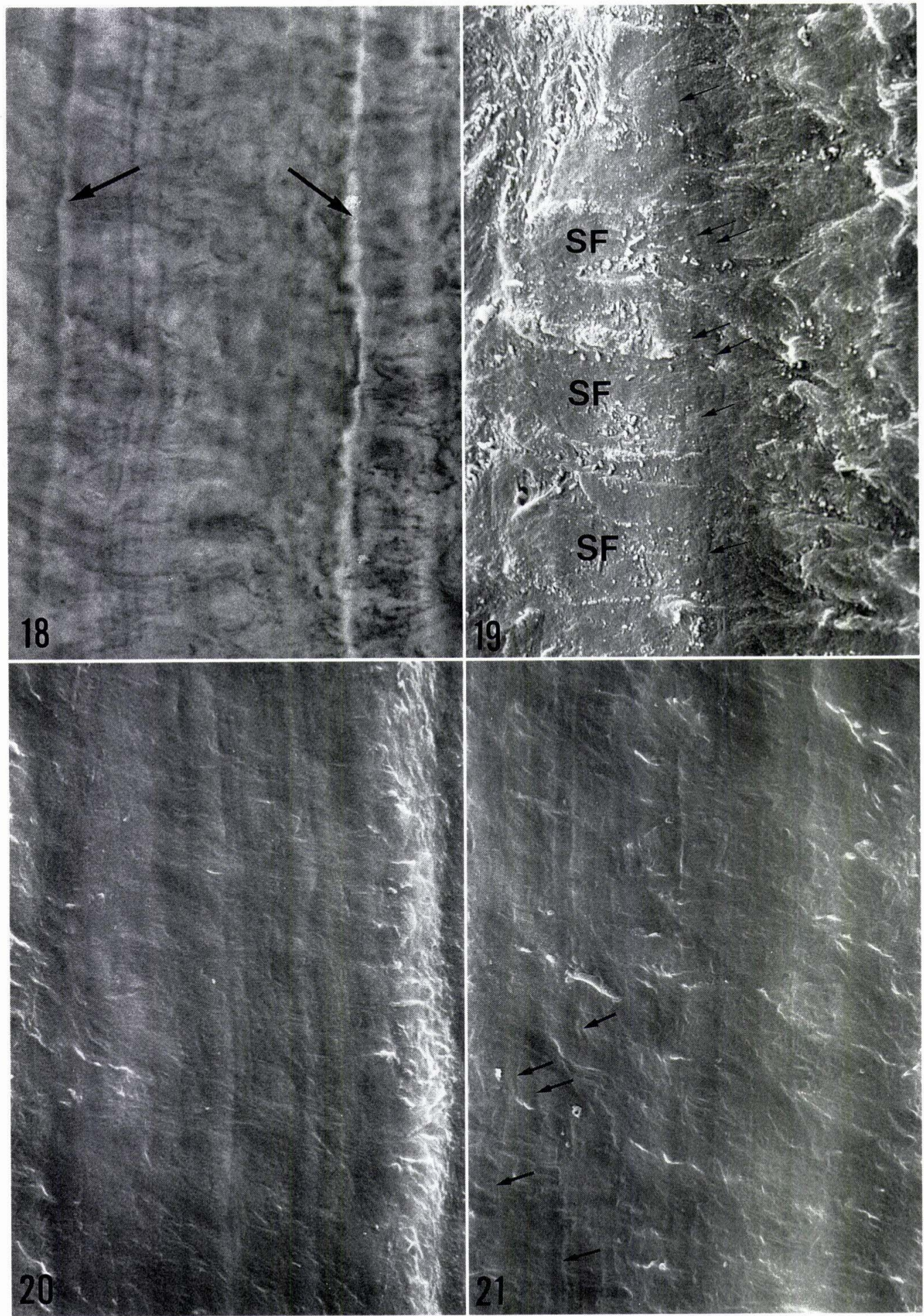


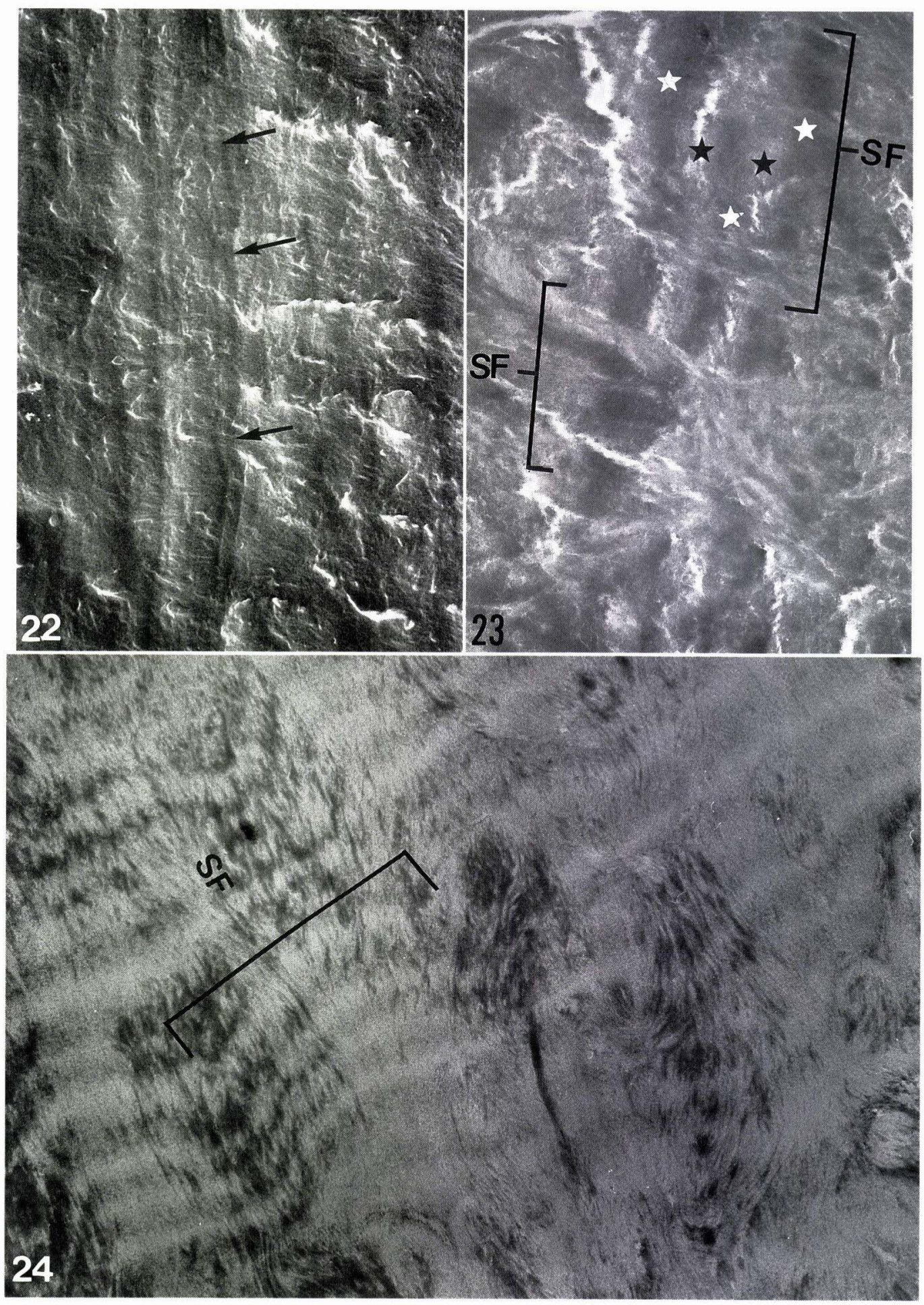




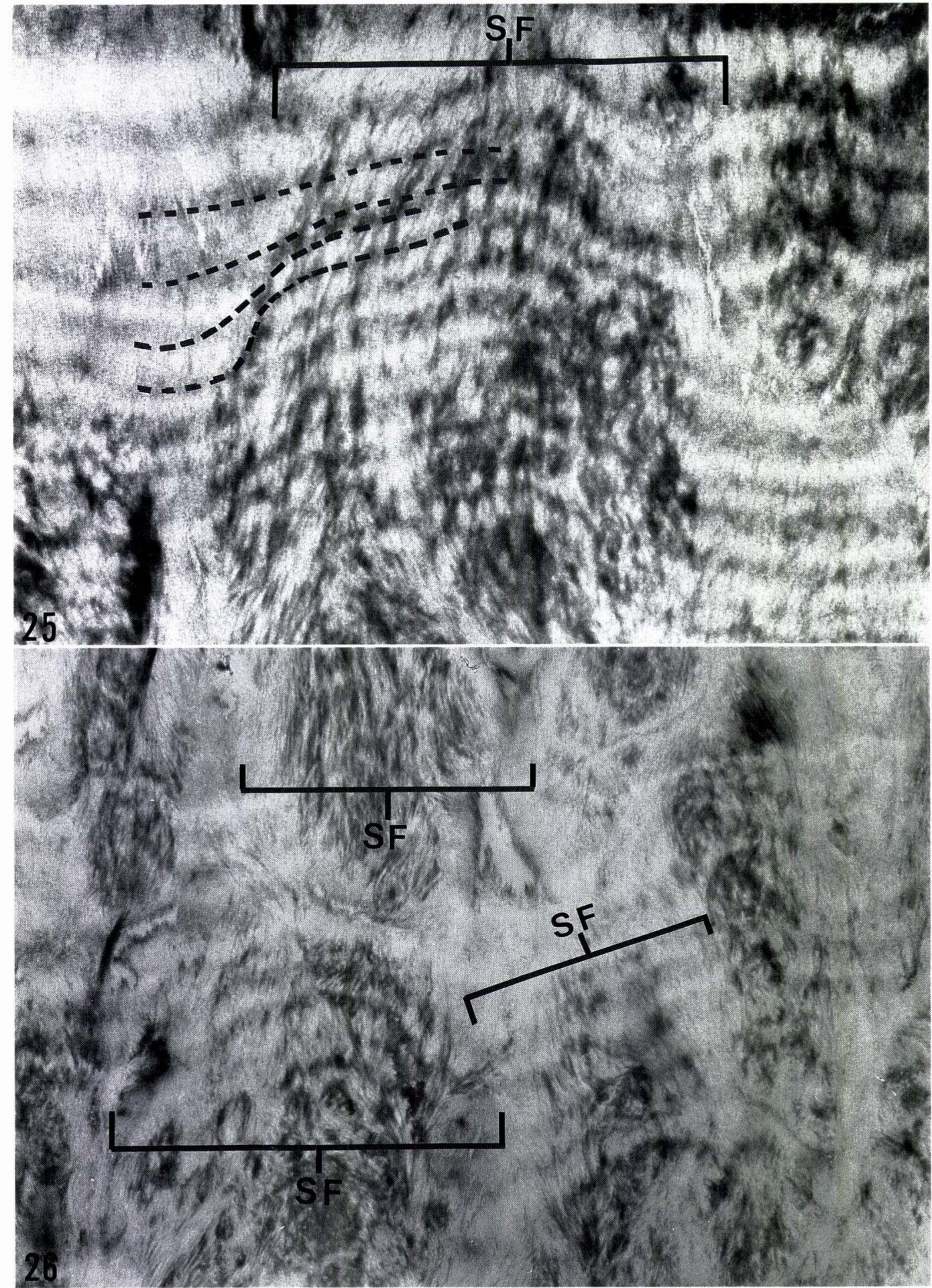



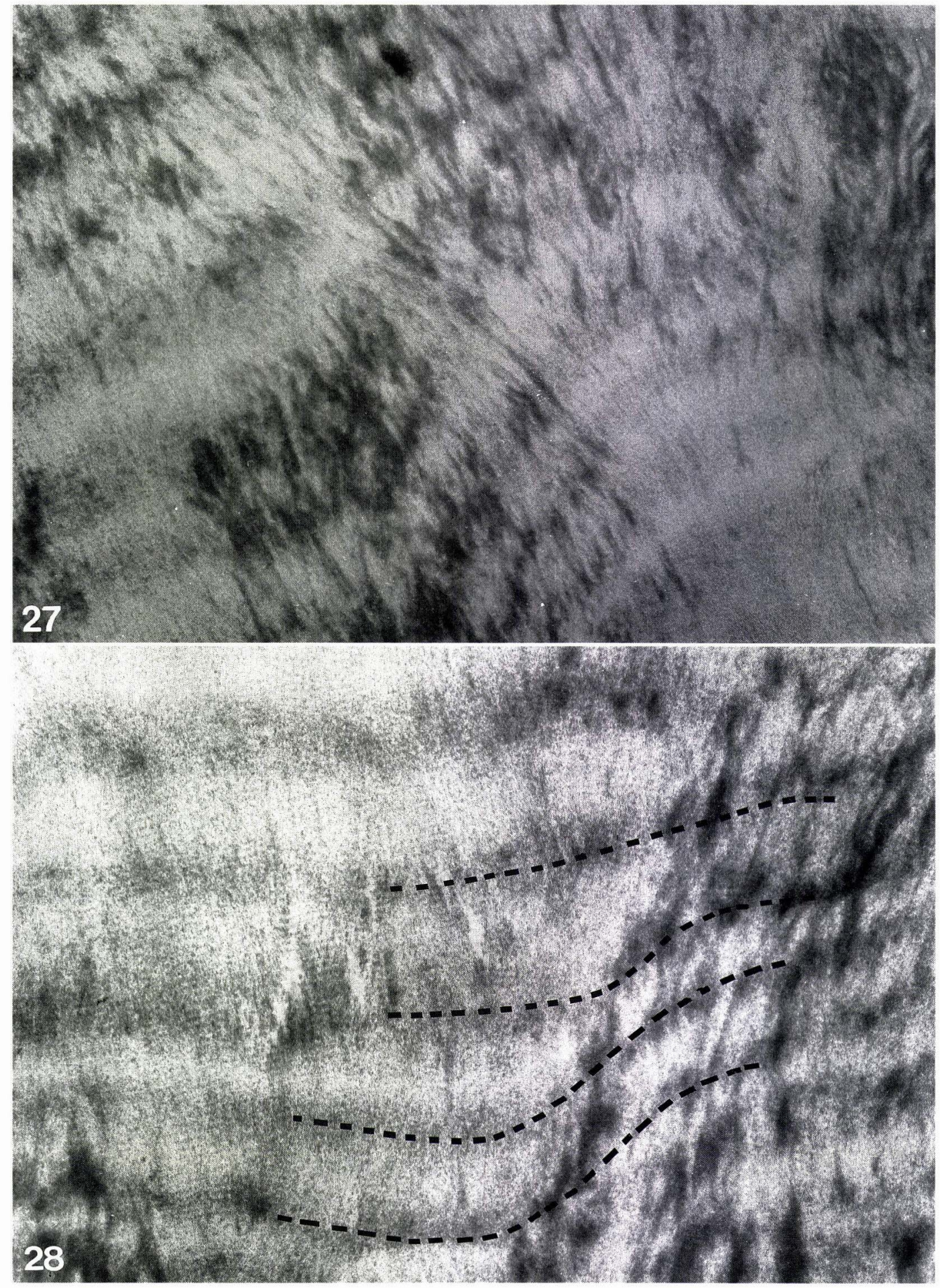